\title{
Are Borders Barriers? The Impact of International and Internal Ethnic Borders on Agricultural Markets in West Africa
}

\author{
Jenny C. Aker, Michael W. Klein, \\ Stephen A. O'Connell and Muzhe Yang
}

\begin{abstract}
This paper addresses two important economic issues for Africa: the contribution of national borders and ethnicity to market segmentation and integration between and within countries. Market pair regression analysis provides evidence of higher conditional price dispersion for both a grain and a cash crop between markets separated by the Niger-Nigeria border than between two markets located in the same country. A regressiondiscontinuity analysis also confirms a significant price change at the international border. The international border effect is lower, however, if the cross-border markets share a common ethnicity. Ethnicity is also linked to higher price dispersion within Niger; we find a significant intranational border effect between markets in different ethnic regions of the country. This suggests that ethnic similarities diminishing international border effects could enhance international market integration, and ethnic differences could contribute to intranational market segmentation in sub-Saharan Africa. We provide suggestive evidence that the primary mechanism behind the internal border effect is related to the role of ethnicity in facilitating access to credit in agricultural markets. We argue that the results are not driven by differences in price volatility or observables across borders.
\end{abstract}

JEL Codes: O1, Q1

Keywords: Africa, border effects, agriculture, regression discontinuity design

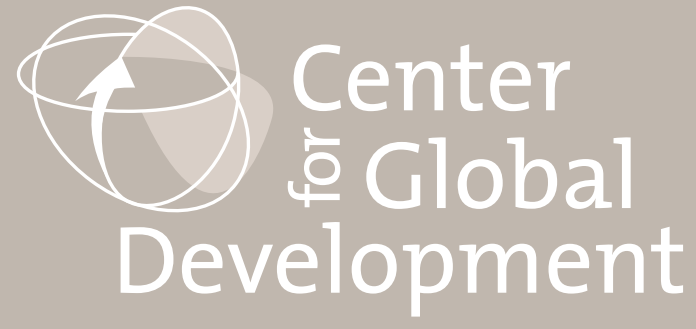

$$
\begin{aligned}
& \text { Working Paper } 208 \\
& \text { April } 2010
\end{aligned}
$$




\title{
Are Borders Barriers? The Impact of International and Internal Ethnic Borders on Agricultural Markets in West Africa
}

\author{
Jenny C. Aker \\ Michael W. Klein \\ Stephen A. O'Connell \\ Muzhe Yang
}

Jenny C. Aker and Michael W. Klein, The Fletcher School and Department of Economics, Tufts University; Jenny.Aker@tufts.edu and Michael.Klein@ tufts.edu; Stephen A. O'Connell, Department of Economics, Swarthmore College, soconne1@swarthmore.edu; Muzhe Yang, Department of Economics, Lehigh University, muzheyang@lehigh.edu. This research was partially funded by the National Bureau of Economic Research Africa Project. We would like to thank seminar participants at the Center for Global Development, National Bureau of Economic Research, Northeast Universities Development Conference (NEUDC), Université de ClermontFerrand and University of Gottingen for their helpful comments and suggestions. All errors are our own.

CGD is grateful for contributions from the William and Flora Hewlett Foundation in support of this work.

Jenny C. Aker et al.. 2010. "Are Borders Barriers? The Impact of International and Internal Ethnic Borders on Agricultural Markets in West Africa." CGD Working Paper 208. Washington, D.C.: Center for Global Development. http://www.cgdev.org/content/ publications/detail/1424038

Center for Global Development 1800 Massachusetts Ave., NW Washington, DC 20036

202.416.4000

(f) 202.416 .4050

www.cgdev.org
The Center for Global Development is an independent, nonprofit policy research organization dedicated to reducing global poverty and inequality and to making globalization work for the poor. Use and dissemination of this Working Paper is encouraged; however, reproduced copies may not be used for commercial purposes. Further usage is permitted under the terms of the Creative Commons License.

The views expressed in this paper are those of the author and should not be attributed to the board of directors or funders of the Center for Global Development. 


\section{Introduction}

There is general agreement among economists that international trade promotes an efficient allocation of resources and, therefore, factors impeding trade impose a deadweight loss.

Additionally, there is evidence that trade contributes to economic growth (Frankel and Romer 1999, Feyrer 2008). These gains from trade are an important motivation for research that gauges the extent to which borders hinder trade among industrialized countries, notably by considering the differences in price dispersion between locations on opposite sides of a national border as compared to between two markets within the same country (Engel and Rogers 1996, Parsley and Wei 2001, Gopinath et al. 2009). ${ }^{1}$

Arguably, the allocative and growth effects of international trade are greater for low-income countries, especially the landlocked countries of sub-Saharan Africa, than for high-income economies. But, even with this greater motivation for estimating the border effects in low-income countries, there has not been much research of the border effect on price dispersion, partly due to the lack of high-frequency data on narrowly-defined goods. In this paper we use monthly price data over an eight-year period for two commodities, millet and cowpea, to assess the degree of market integration across the border of Niger and Nigeria. Niger is a landlocked former French colony, and is ranked last on the human development index, whereas Nigeria is a former British colony and

\footnotetext{
1 As discussed in more detail below, the magnitude of these estimates has been questioned by Gorodnichenko and Tesar (2009) who show that differences in underlying price volatility across countries contribute to the estimated border effect, and that this accounts for a large upward bias in the Engel and Rogers (1996) result, and others that follow their research design.
} 
Africa's most populous country. We also consider the role of ethnicity in both mitigating the international border effect between markets that share a common ethnic make-up, and in giving rise to a border effect within Niger between markets that are located in different ethnic regions.

Our analysis addresses two central issues in African political economy. The first concerns the economic salience of political boundaries in Africa and the degree to which these borders restrict cross-border trade. The second relates to the economic effects of ethno-linguistic fractionalization within African countries.

Cross-border trade is extensive throughout West Africa, including along the Niger-Nigeria border. The extent of trade between the two countries is partly due to the absence of any natural impediments between Niger and Nigeria, such as rivers or mountains. ${ }^{2}$ Rather, the border between the two countries, created by the United Kingdom and France in the wake of the 1884-85 Berlin Conference, was drawn through a region within which the Hausa ethnic group had historically supported an active trade in livestock, textiles, salt, kola nuts, and food staples (Anene 1970, Hopkins 1973, Miles 1994).

The manner in which the Niger-Nigeria border divided an ethnically homogeneous region between two countries is not unique in Africa (Asiwaju 1985). Nor is Niger unusual in its inclusion of a number of ethnic groups whose people live in geographically distinct regions of the country. An extensive literature explores the effects of ethno-linguistic fractionalization on a variety of outcomes, showing that higher levels of ethnic diversity within a country are associated with lower growth rates (Easterly and Levine 1997), more corruption (Mauro 1995), lower contributions to local public goods (Alesina, Baqir and Easterly, 1999) and lower participation in groups and associations (Alesina and La Ferrara 2000). We are not aware of any other studies of the effect of de

\footnotetext{
${ }^{2}$ The Niger River is the principal river of West Africa, extending 4,180 km. The river's source starts in Guinea and empties into the Niger Delta, in southern Nigeria. While the river traverses both Niger and Nigeria, it only forms a border between Niger and Benin, rather than between Niger and Nigeria.
} 
facto intra-national borders, arising from the presence of ethnic diversity, on market segmentation within Africa. ${ }^{3}$

We contribute to these central topics of research by assessing the importance of national borders for agricultural market integration and segmentation. We simultaneously consider the impact of ethnicity on trade, both across international borders and across the de facto boundaries that separate ethnic regions within a country. Our analysis focuses on two agricultural products, millet and cowpea, which are produced and consumed in both countries and were traded freely during our sample period. We use two primary datasets, both of which were collected by one of the authors (Aker). The first consists of monthly prices of millet and cowpeas across forty-two markets in Niger and Nigeria between 1999 and 2007. The second includes data on covariates that partially explain price dispersion across markets, including road distances, transportation costs, mobile phone coverage, rainfall, and the ethnicity of traders, farmers and transporters in local markets.

We use two empirical approaches to analyze the border effect. The first is a regressionbased method using market pairs, whereas the second is a regression discontinuity (RD) design. We present evidence that the international border increases price dispersion across markets for millet and cowpeas. The regression-based estimate of the effect of the Niger-Nigeria border on price dispersion across markets, conditional on transport costs and other characteristics, is 2.5 to 3 percent for both millet and cowpeas. This represents a distance-equivalent effect of 2.2 kilometers, which is quite modest as compared to results found for industrial countries. We find a much larger effect for a single market (on either side of the border) using the RD design, with a border effect of close to 20 percent of the price of millet, and a slightly larger effect for cowpeas. The identification

\footnotetext{
${ }^{3}$ Studies of cross-border trade in West Africa have typically been restricted to a few locations and time periods (See Azam (2007) for an overview). The paper closest to our own is Araujo-Bonjean et al. (2008), who estimate a vector autoregression in monthly marketlevel millet prices for national markets in Niger, Mali and Burkina Faso. Cross-sectional regressions on these estimated coefficients uncover a statistically significant border effect within the Communauté Financière Africaine (CFA) zone.
} 
of a border effect in our empirical setting is bolstered by the absence of geographic features that could impede trade, such as rivers or mountains, between Niger and Nigeria.

We also find evidence of an important role of ethnicity as a source of market integration and segmentation in these two West African countries. Our estimates suggest that different ethnic groups create an "internal barrier" to trade between the Hausa and the Zarma regions of Niger, as compared to trade within either ethnic region. This "internal (ethnic) border effect" is statistically significant and larger in magnitude than the international border effect. But ethnicity also facilitates market integration, since the international border effect is significantly smaller between the Hausa regions of Niger and Nigeria than between two cross-border markets that do not share a common ethnic composition.

We provide suggestive evidence of the trader-level mechanisms behind the ethnic border effect within Niger. The internal border effect does not appear to be explained by differential investments in the Hausa and Zarma regions, nor by an absence of trade between these two regions. Rather, the border effect appears to be associated with the role of gender in the two cultures, as well as the importance of ethnic social networks in facilitating access to credit.

The rest of the paper is structured as follows. Section 2 provides a context for our analysis by discussing some relevant characteristics of Niger, including agricultural trade patterns, the geographic nature of ethnic groupings and establishment of its international border with Nigeria. Section 3 describes the data and provides descriptive statistics. Section 4 discusses the empirical strategy, and Section 5 presents the results for the international border effect. Section 6 investigates the role of ethnic diversity on creating internal barriers. Section 7 concludes. 


\section{Agricultural Trade in Niger}

Niger is one of the poorest countries in the world, ranking last on the United Nations' Human Development Index (UNDP 2009). The majority of the population consists of rural subsistence farmers, who depend upon rain-fed agriculture as their main source of food and income. As a landlocked country, Niger depends upon trade with its contiguous neighbors, primarily the coastal countries of Benin and Nigeria, but also the landlocked countries of Burkina Faso and Mali.

Niger's trade links with its coastal neighbors have a long and rich history. In the centuries prior to the arrival of the colonial powers, the Hausa ethnic group in modern-day Northern Nigeria and Niger was linked to the rest of the continent through a set of long-distance trading routes. One of these was the northerly trans-Saharan trade route connecting Katsina and Kano (Nigeria) to Tripoli (Libya) via Niger. Trade along this route was primarily in slaves, textiles, livestock, grains and salt. A second route was the westward trade in kola nuts between Niger and Nigeria and what is now Ghana (Hashim and Meager 1999). ${ }^{4}$

There were a number of significant changes in these circuits during the 1800 s, when the slave trade became less important in the export portfolio of West African states and European imports became increasingly important (Hashim and Meager 1999). In addition, an eastward shift in the trans-Saharan trade route coincided with a dramatic expansion of the economy of Sudan. As Hausa trading networks became more dominant, Hausa became the lingua franca along the east-west trading routes (Lovejoy 1980). Nevertheless, the direction and composition of the trade routes during that time were still primarily based upon ecological specialization and comparative advantage.

At the end of the $19^{\text {th }}$ century, in the wake of the $1884-85$ Berlin Conference, the $1,500-\mathrm{km}$ border between the French colony of Niger and the British colony of Nigeria was established

\footnotetext{
${ }^{4}$ The kola nut is native to the tropical rainforests of Africa. It is chewed in many West African cultures to restore vitality and to ease hunger pangs. In addition to these primary trading circuits, there was also an east-west route between Kano and Mecca, whereby pilgrimage was combined with trade.
} 
(Figure 1). The border's placement reflected the opposing territorial interests of the French and British colonial administrations; the French government wanted access to Chad across southern Niger, thus moving the border from the northern desert regions to a location within the arable zone further south, while the British government insisted that the Hausa-Fulani kingdoms of northern Nigeria be kept intact, in light of previous civil conflict between the groups. The border that emerged in 1906 divided the Hausa, Fulani and Kanuri ethnic groups between the two countries. ${ }^{5}$ It also created a Niger that included eight primary ethnic groups (Hausa, Songhai/Zarma, Toureg, Fulani, Kanuri, Arab, Toubou and Gourmantche) which were, for the most part, situated in geographically distinct regions. ${ }^{6}$

At present, trade between Niger and Nigeria is dominated by trade in agro-pastoral products (grains, legumes and livestock), and petroleum and farm-chemical products. Both countries are members of the Economic Community of West African States (ECOWAS), a customs union among all West African states; trade in locally-produced food staples is largely free, so evidence of an international border effect during most of our sample period (1999 - 2007) cannot be attributed to official trade restrictions. One possible source of trade friction arises from currency exchange costs between the Communauté Financière Africaine (CFA) franc of Niger and the Nigerian naira.

Furthermore, linguistic differences (between the official languages of Niger and Nigeria, French and English, respectively) could also add to transaction costs. There could also be costs due to delays or harassment at the border, or banditry in the border region. ${ }^{7}$ Few road networks were developed linking Niger and Nigeria during the colonial period, and, for this reason, there were relatively few

\footnotetext{
${ }^{5}$ The Niger-Nigeria border created a 'partitioned culture area' among Hausa and Fulani populations, one of many such areas in contemporary Africa (Asiwaju 1985). At the outset of the international demarcation, inhabitants with farmland straddling the boundary had to choose one colonial side or the other, as French subjects were not supposed to farm on British territory, and vice versa (Miles 2005).

${ }^{6}$ A map of Nigeria in 1957-58 suggests that the geographic location of ethnic groups is similar to the ethnographic maps for 2008. ${ }^{7}$ Despite a series of border closings between 1983 and 1986, often related to political instability in Nigeria, both the National Boundary Commission of Nigeria and the Nigeria-Niger Joint Commission convened trans-border workshops to address issues of cross-border trade.
} 
official border crossing stations by the time of independence in $1960 .^{8}$ Building more crossing stations was a low priority for the newly independent and relatively poor states of Nigeria and Niger. Consequently, borders remained porous, patrolling haphazard, and smuggling a major economic activity for petroleum and taxed agricultural products (Charlick 1991).

\section{Empirical Strategy}

If borders impose costs that hinder trade, then, conditional on distance between markets and other location-specific factors, price differences between markets located in different countries should be larger than those between markets in the same country. Similarly, for two proximate markets on either side of the border, the price of a homogeneous good will differ between these markets if the border imposes transaction costs. In this paper, we employ two different empirical strategies to estimate the border effect: a regression-based analysis that examines price differences across market pairs, and an RD design focused on the difference in cross-border prices for markets that are close to the border.

\section{Market-Pair Regression}

Most market-pair regression analyses of the border effect regress a measure of price dispersion between market pairs on a border indicator variable and other covariates (Engel and Rogers 1996, Parsley and Wei 2001, Ceglowski 2003). For example, Engel and Rogers (1996) compare price differences for 14 categories of goods among 228 pairs of cities in the United States and Canada using a specification that regresses price dispersion between two cities on the log of distance between those cities, a border indicator and a set of city-specific fixed effects. The

\footnotetext{
${ }^{8}$ The British completed a railway between Lagos (southern Nigeria) and Kano (northern Nigeria) in 1911, unifying Nigeria's coast with its north-eastern interior and undermining the long-distance trade between Kano and Tripoli (Hopkins 1973).
} 
coefficient estimate of the border indicator represents the change in price dispersion between two cities due to the fact that they are in different countries. ${ }^{9}$

Engel and Rogers (1996) find strikingly large effects of the international border on price dispersion: one estimate puts the distance-equivalent effect at over 70,000 kilometers. Other research reports similar magnitudes for border effects between industrial countries. However, Gorodnichenko and Tesar (2009) show that differences in underlying price volatility in two countries can bias the estimate of the border effect upward since comparing cross-country pairs of prices reflects not only the costs associated with crossing the border, but also any differences in underlying price variability between the countries. They demonstrate that controlling for countryspecific volatility can result in very different estimates of the border effect. ${ }^{10}$ Using the Engel and Rogers' (1996) data, the estimated distance-equivalent border effect based on a specification that includes a Canada-Canada fixed effect is 47 kilometers, whereas the distance-equivalent border effect after controlling for a US-US fixed effect is 108 million kilometers.

The specification we use for our market-pair estimation is:

$$
\left|\ln \left(p_{j t}^{i} / p_{k t}^{i}\right)\right|=\beta_{0}+\beta_{1} B_{j k}+X_{j k t}^{\prime} \beta_{2}+\sum_{m=1}^{M} D_{m}^{\prime} \gamma_{m}+\theta_{t}+\varepsilon_{j k t},
$$

where $p_{j t}^{i}$ and $p_{k t}^{i}$ are the prices of a good $i$ in markets $j$ and $k$, respectively; $B_{j k}$ is an indicator variable equal to 1 if there is an international border between the two markets $j$ and $k$; $X_{j k t}$ is a vector of variables that can affect price dispersion between the two markets, such as drought, transport costs, mobile phone coverage and other time-varying factors; $D_{\mathrm{m}}$ is a vector of marketspecific dummy variables; $\gamma_{m}$ represents the market-level fixed effect; and $\theta_{t}$ denotes monthly time

\footnotetext{
${ }^{9}$ Using this specification, the authors can calculate a distance-equivalent effect using the parameter estimates for the border effect and distance.

${ }^{10}$ Gorodnichenko and Tesar (2009) control for country-specific variability by including indicator variables for Canada-Canada market pairs in one specification, and US-US market pairs in another. As they discuss, it is not possible to control for both effects simultaneously due to perfect multicollinearity with the border indicator variable.
} 
effects. ${ }^{11}$ This specification implies that on average there is a percentage change in the magnitude of price differences exclusively attributable to the presence of the border, conditional on market-level observables and common shocks across markets. However, for a pair of markets located far away from the border and in different countries, the country-level unobserved heterogeneities can confound the border effect. For this reason, we restrict our analysis to market pairs no more than 250 kilometers apart. Because equation (1) is a dyadic time series regression, we correct the standard errors by including market-specific fixed effects and clustering at the monthly level, as well as by employing dyadic standard errors (Fafchamps and Gubert 2007). Finally, mindful of the Gorodnichenko and Tesar (2009) critique, we also examine the stability of the estimated border effect by including indicator variables for country-specific pairs.

\section{Regression Discontinuity Design}

An advantage of regression discontinuity $(\mathrm{RD})$ design in this context is its robustness to confounding factors. By construction, the RD design focuses on subjects proximate to a treatment threshold which, in our empirical setting, is the international border. Close to the border, crossborder markets are likely to share, on average, common unobservables. Therefore, any observed (or detected) price differences between cross-border markets, conditional on their observable characteristics, are likely to be due to the institutionalized border. This is particularly relevant in our context, as the Niger-Nigeria border is not formed by natural features such as rivers, lakes or mountains. An analysis of covariates for those markets close to the border helps assure us that price differences in cross-border markets do not reflect discontinuities at the border in observable factors.

We use an RD design in which the assignment variable is a market's distance to the border, and the "treatment" status is whether the market is located in Niger or Nigeria, in the case of the international border. This follows the work of Gopinath, Gourinchas, Hsieh, and Li (2009), who

\footnotetext{
${ }^{11} \mathrm{~A}$ variable for distance between two markets is not included as an additional covariate because the transport cost between two markets is a function of their distance between each other.
} 
estimate the effect of the US-Canada border on supermarket prices in each country. Our regression discontinuity model is

$$
\ln p_{j t}^{i}=\delta_{0}+\delta_{1} N_{j}+\delta_{2} D_{j}+\delta_{3} D_{j} * N_{j}+X_{j t}^{\prime} \delta_{4}+\theta_{t}+\varepsilon_{j t}
$$

where $p_{j t}^{i}$ is the price of a good $i$ in market $j$ at time $t ; N_{j}$ is an indicator variable equal to 1 if market $j$ is in Niger and 0 if it is in Nigeria; $D_{j}$ is the distance from market $j$ to the international border (with $D_{j}<0$ for markets in Nigeria and $D_{j}>0$ for markets in Niger); $X_{j t}$ is a vector of variables that affect prices in market $j$, such as drought or mobile phone coverage; and $\theta_{t}$ denotes monthly time effects. We also include the latitude and longitude of market $j$ as proxies for location-specific time-invariant unobservable characteristics of market $j$ in some specifications. ${ }^{12}$ The border effect is given by the parameter $\delta_{1}$, which implies a price change by simply relocating a market across the border. For the estimation, we restrict the sample to those markets that are located within a certain distance (in kilometers) of the border; this approach is equivalent to a uniform kernel regression (Imbens and Lemieux 2008).

\section{Data and Measurement}

This study constructs four datasets, based upon primary and secondary data collected by one of the authors. The first includes monthly price data for millet and cowpea over an eight-year period (1999 to 2007). These data were collected from Niger's Agricultural Market Information System (AMIS) and include prices from 42 markets in Niger and northern Nigeria. Millet is a staple grain in both countries and is produced and consumed in almost all regions, with the exception of the northern desert regions of Niger. Cowpea is similarly produced in most agro-climatic zones, but

\footnotetext{
${ }^{12}$ We interact the border term with distance to the border to show how the border effect changes with distance to the border, and also to be consistent with Gopinath, Gourinchas, Hsieh, and Li's (2009) approach. The latitude and longitude coordinates for each market serve as control variables for time-invariant heterogeneities that vary continuously across geographical space..
} 
primarily functions as a cash crop for rural households in Niger. Cowpea is highly sensitive to pest infestations, and is consequently more perishable than millet. While region-specific differences exist in the quality and size of both commodities, they are considered to be homogeneous goods to farmers and traders. ${ }^{13}$ Both millet and cowpeas are heavily traded across the Niger-Nigeria border.

The second dataset includes information on the latitude and longitude of each market, the location of the international border, and the road distances between market pairs. These data enable us to calculate the Euclidean and road distances between market pairs, as well as the distance from each market to the international border.

The third dataset includes data on a variety of covariates that affect price dispersion across agricultural markets in West Africa, including monthly gas prices, rainfall, road quality, district-level population size, the date of initiation of mobile phone coverage and the Naira-CFA exchange rate. These data were collected from a variety of primary and secondary sources, including the Direction de la Meteo, the mobile phone companies and the Nigerien oil company (SONIDEP).

The fourth dataset is a unique panel survey of traders, transporters and market resource persons collected by Aker between 2005 and 2007. These survey data draw on interviews with 415 traders and 205 farmers located in 35 markets and 40 villages across 6 geographic regions of Niger and northern Nigeria. Traders and market resource persons who participated in the survey provided detailed information about their demographic and socio-economic background and commercial operations. These data also allow us to construct measures of the ethnic composition of each market and village and to identify ethnic "borders."

Table 1 presents summary statistics for the data from 1999 to 2007. Panel A includes data for market pairs in Niger and Nigeria, whereas Panel B includes data for markets within in each country that are located within 250 kilometers of the international border. The average price

\footnotetext{
${ }^{13}$ Aker (2008) shows that there are no price premiums for millet or cowpea based upon color, grain size and quality.
} 
$(\mathrm{CFA} / \mathrm{kg})$ for millet is higher in Niger than in Nigeria, with a statistically significant difference between the two (Panel B). This is consistent with the direction of trade between the two countries, as Niger is a net importer of millet from Nigeria. In contrast, average cowpea prices are lower in Niger (although the difference is not statistically significant) and Niger exports cowpeas to Nigeria. In Panel B, we do not reject the equality of means for most observable characteristics, with the exception of the Zarma ethnic group and the frequency of urban centers. The Nigerian markets in our sample are only composed of the Hausa and Kanuri ethnic groups. ${ }^{14}$

\section{The International Border Effect}

\subsection{Market Pair Regression Results}

Table 2 shows the regression results for equation (1) for both millet and cowpea, for market pairs that are within 250 kilometers of each other. Column 1 shows a statistically significant increase in millet price dispersion of 2.1 percent due to the international border. The border effect increases slightly when other covariates are included in the regression, such as the log of transport costs, drought and mobile phone coverage (Column 2). The border effect is also robust to the inclusion of country-pair fixed effects for Niger (Column 3) and Nigeria (Column 4). The coefficient does not change when an indicator variable for intra-Niger pairs is included (Column 3 compared with Column 2), and increases only slightly when the indicator variable for intra-Nigeria pairs is included (Column 4 compared with Column 3). The small change in the magnitude of the border effect after controlling for country-pair fixed effects contrasts starkly with Gorodnichenko and Tesar (2009), who found large differences when including country-pair fixed effects for the US and Canada. The border effect also remains positive and statistically significant when market-specific fixed effects are

\footnotetext{
${ }^{14}$ While members of the Zarma ethnic group live within Nigeria, the Zarma constitute a small percentage of the population (approximately 88,000 people, or less than 0.0007 percent) and is geographically focused in the far northwestern region of the country on the border with Benin and Niger (Birin n'Kebbi region).
} 
included (Column 5). These results are robust to using dyadic standard errors to adjust for the spatial dependence generated by a commonly shared market for different market pairs.

While equation (1) does not include distance as a covariate because of its collinearity with transport costs, it is instructive to calculate a km-equivalent border effect for millet to provide a context for our results. A regression that includes the log of distance, rather than transport costs, gives a kilometer-equivalent value of the border of 2.2 kilometers, which is far lower than the estimates found in industrialized countries (Gorodnichenko and Tesar 2009). ${ }^{15}$ The regression results for millet in Table 2 translate into an average transport-cost-equivalent effect of 1.65 $\mathrm{CFA} / \mathrm{kg} / \mathrm{km}$, compared with an average millet price of $124 \mathrm{CFA} / \mathrm{kg}$ in Niger and $113 \mathrm{CFA} / \mathrm{kg}$ in Nigeria.

Columns 7 to 12 present the regression results for cowpeas. Controlling for the international border, we find a statistically significant increase of 1.9 percent in price dispersion across markets (Column 7). The effect is robust to the inclusion of other covariates (Column 8), but its magnitude increases slightly. Unlike the results for millet, the magnitude of the border effect is more sensitive to the inclusion of indicator variables for intra-Niger and intra-Nigeria market pairs, suggesting that there could be underlying country-specific differences in price volatilities for cowpeas (Columns 9 and 10). Nevertheless, the km-equivalent border effect is still only $2.8 \mathrm{~km}$ and the transport-cost equivalent effect is $1.65 \mathrm{CFA} / \mathrm{kg} / \mathrm{km}$, similar to the effects for millet.

We extend the model in equation (1) to consider the potential role of ethnicity in trade and cross-border price dispersion (Columns 6 and 12). The estimates in these columns include two additional variables in the regression, an indicator variable for ethnicity (equal to 1 if both markets in a pair are dominated by the same ethnic group, 0 otherwise), and an interaction term between

\footnotetext{
${ }^{15}$ The dependent variable used by Engels and Rogers (1996) is price volatility, measured as the standard deviation of the log of relative prices between two locations. For this reason, the calculation and interpretation of the km-equivalent border effect is not strictly the same between our model and theirs.
} 
ethnicity and the border indicator. In this specification, the effect of the border on price dispersion in villages with different ethnicities is represented by the coefficient on the border indicator. The effect of the border across two markets with a common ethnicity is represented by the sum of the coefficient on the border indicator and the coefficient on the interaction term. The effect of a common ethnicity on price dispersion between two markets in the same country is captured by the coefficient on the intra-ethnic dummy variable while the effect of ethnicity on prices in two markets in different countries is represented by the sum of this coefficient and the coefficient on the interaction variable.

The results presented in Column (6) show that millet price dispersion between intra-ethnic market pairs within the same country is 1.4 percent lower than price dispersion between inter-ethnic market pairs, although there is not a similar significant effect for cowpea (Column 12). For those cross-border markets, having a common ethnicity lowers the price dispersion by 1.9 percent for millet (Column 6) and 2.8 percent for cowpea (Column 12). Common ethnicity reduces price dispersion by 3.3 percent for millet (Column 6) and 3.1 percent for cowpeas (Column 12). The composite effect of the international border on raising the price dispersion is 2.5 percent for millet (Column 6) and nearly zero for cowpea (Column 12), suggesting that the border effect could be countervailed by the effect of having a common ethnicity across the border. We explore the role of ethnicity in more detail in Section 6.

\subsection{Regression Discontinuity Results}

An alternative to controlling for distance explicitly is to focus on markets located close to the international border that are likely to on average have similar observable and unobservable characteristics. In Figures 2 and 3, we plot the time series of the average differences in the log of prices of millet and cowpeas for those markets located within $5-\mathrm{km}$ and $50-\mathrm{km}$ of the international border. The figures show that there is a wide seasonal variation in prices, with the average 
differences in the log of prices range from -3 to 25 percent. Average prices are typically higher in Niger, especially for millet.

The unconditional price differences in these figures can be analyzed in a more rigorous manner using an $\mathrm{RD}$ design. The $\mathrm{RD}$ results for millet are presented in Table 3, and for cowpea in Table 4. In the regressions underlying these tables, the key variable of interest is "Niger", indicating whether a market is in Niger (1) or Nigeria (0). A significant coefficient estimate on this variable indicates a discontinuous change in prices between proximate markets in Niger and Nigeria, conditional on the covariates included in the regression.

The estimates showing a higher price for millet in Niger than in proximate markets in Nigeria presented in Table 3 are consistent with Figure 3. The results confirm a statistically significant international border effect for millet, with millet prices increasing by about 22.5 percent at the international border (Column 1) when the bandwidth is 5 kilometers. These findings are robust to the inclusion of other covariates that could affect price changes (Column 2), including monthly time effects and the latitude and longitude of the market (Column 3). Comparable specifications that use all markets within $50-\mathrm{km}$ of the border offer similar results (Columns 5 to 7 ), although the magnitude of the border effect is diminished relative to the $5-\mathrm{km}$ results. This suggests that, as the set of markets expands to include those farther from the border, more of the price variation of millet can be explained by the differences between Niger and Nigeria in addition to the border alone. For the full sample estimation, we find that the border effect is indeed mitigated, possibly due to the country-level heterogeneities (Columns 9 and 12).

The border effect for the price of millet is smaller between markets of common ethnicity than between markets with different ethnicities. Columns 4 and 8 demonstrate this effect by including two additional variables in the specifications, a Hausa indicator variable (equal to 1 if traders operating in the market are primarily from the Hausa ethnic group, 0 otherwise) and an 
interaction term between the Hausa and Niger indicator variables. The sum of the coefficient on the Niger indicator variable and the interaction term shows the price difference when one crosses the border from a Hausa market in Nigeria to a proximate Hausa market in Niger. The results in Column 4 suggest that prices increase by 9.3 percent when crossing the border from one Hausa market to another (and this is not statistically significant), rather than the 23.2 percent border effect for cross-border markets which do not share the same ethnicity (and, in this case, the effect is statistically significant). Thus, common ethnicity mitigates the international border effect. The effect of ethnicity on the border is even more marked when considering markets within $50 \mathrm{~km}$ of the international border. As shown in Column 8, the border effect for different ethnicities in this case is 20.8 percent, and for a common ethnicity is approximately 1.3 percent.

The RD results for cowpea (Table 4) are consistent with those for millet. Cowpea prices change by about 27 percent at the border (Column 1), and the significance of this effect is robust to the inclusion of other covariates (Column 2), monthly time effects, and the latitude and longitude of the market (Column 3). As in the case of millet, common ethnicity mitigates the border effect. The results in Column 4 show that the border effect is 40 percent bigger when cross-border markets are comprised of different ethnic groups (with a border effect of 20.2 percent), as compared to when they share a common ethnicity (in which case the border effect is 14.4 percent). With the wider bandwidth, there is no evidence of a significant border effect when the cross-border markets are both Hausa (Column 8).

\subsection{Alternative Explanations for the Border Effect}

We are concerned about attributing conditional price differences to a border effect when they reflect sources other than purely the nation in which markets are located. In this subsection, we conduct a variety of robustness checks.

\section{Differences in Underlying Price Volatilities for Market Pairs}


Gorodnichenko and Tesar (2009) criticize the existing literature on border effects for being underidentified, as it does not control for differences in underlying price volatility in each country. We address concerns about differences in underlying price volatility in each country by considering the kernel distributions of conditional price differences for market pairs. We estimate the regression model:

$$
\left|\ln \left(p_{j t}^{i} / p_{k t}^{i}\right)\right|=\gamma_{0}+X_{j k t}^{\prime} \gamma_{1}+\theta_{t}+a_{j k}+\varepsilon_{j k t}
$$

where $p_{j t}^{i}, p_{k t}^{i}, X_{j k t}$ and $\theta_{t}$ are the same as those previously defined in equation (1). In some specifications, we also include market-pair fixed effects, $\alpha_{j \mathrm{k}}$. The two panels of Figure 4 plot the kernel densities of the residuals from a regression model (equation 3) to examine relative conditional deviations from the Law of One Price for millet and cowpea. Similar to the regression-based results, visual inspection of the kernel densities of the residuals suggests that the underlying volatilities of market-pair price differences are similar both across and within countries for millet and cowpea.

\section{Differences in Market-Level Observables}

A key identification assumption of the RD design is that neither observable nor unobservable determinants of the outcome change discontinuously at the border. While it is impossible to directly test for such an identification assumption for unobservable characteristics, we can test whether the observed characteristics of those markets located near the border are similar, on average. One possible reason for differences in determinants in a border analysis is the presence of natural barriers such as rivers or mountains, but this is not the case for the border between Niger and Nigeria. Table 5 tests for this more formally by comparing the equality of means for most observables for markets located within 5 and $50 \mathrm{~km}$ of the border. ${ }^{16}$ We do not find a statistically significant difference for most observables for these markets. The notable exception is mobile

\footnotetext{
${ }^{16}$ The equality of means for other covariates, such as market size, the market tax and the number of police controls were also tested, with no statistically significant difference between the two groups.
} 
phone coverage, as markets in northern Nigeria received coverage later than markets in Niger.

These results suggest that the border effect is not serving as a proxy for cross-border differences in these other factors.

\section{Market Segmentation}

The presence of the international border could be a proxy for factors that limit trade between two markets in neighboring countries. Although we do not have time series data on trade volumes or trade flows between 1999 and 2007, we could identify certain barriers to trade that operate on either side of the border from our trader-level data, if those barriers were present. These data include purchase and sales markets of traders operating on the market, as well as the average volume of agricultural products traded at different periods of the year. Table 6 shows that between 2004 and 2007, 27 percent of traders in Nigerien markets located 50 kilometers from the international border traded millet and cowpea with traders in northern Nigeria, whereas 55 percent of Nigerian traders bought and sold agricultural products from Nigerien markets across the border. While the quantities of agricultural products traded differ significantly by the period of year, there is not a statistically significant difference in the average volume bought and sold by traders operating in Niger and northern Nigeria during this time period. In addition, there was no statistically significant difference in the number of traders operating on each market, nor on the number of police controls. This suggests that market segmentation, as defined by the absence of trade between the cross-border markets, is not the driving force behind the border effect.

\section{The Internal Ethnic Border Effect}

Our previous results show that a common ethnicity can diminish the effect of an international border on price differences between countries. Does a converse result hold as well, whereby there is a de facto border within a country, across its ethnic regions? Niger offers a good 
setting for addressing this type of question since there is a strong geographic separation among ethnic groups. However, in this way Niger is not atypical among countries in sub-Saharan Africa, where countries are comprised of a diverse set of ethnic groups. Despite the prevalence of this characteristic across countries, we know of no other studies on the effect of spatial ethnic diversity on intra-national market segmentation.

We begin this section by using an RD design to estimate the impact of internal ethnic borders on millet and cowpea prices across regions within Niger. We then offer some potential explanations for this effect and attempt to reject alternative explanations.

\subsection{Regression Discontinuity Analysis of the Internal Ethnic Border}

We use both primary and secondary data on the ethnic composition of villages in Niger during two periods to identify internal ethnic borders. Using census data, we first calculate the ethnic composition of each market between 1999 and 2007, identifying those markets with both low (i.e., purely Hausa or purely Zarma) and high degrees of ethnic diversity. The internal "ethnic" border is identified by a set of geographic coordinates for markets with a high degree of ethnic diversity and which separate two geographic regions with a low degree of diversity (that is, a strong majority of Hausa or majority of Zarma).

Table 7 shows the equality of means for market-level observables on either side of this intraNiger ethnic border, at various distances from this border $(<20 \mathrm{~km},<30 \mathrm{~km},>100 \mathrm{~km}$, or all markets). We do not find a statistically significant difference in the means for most market-level observables, including the frequency of drought, urban status, the number of police controls, market size and the market tax. ${ }^{17}$ The notable exception is mobile phone coverage, with a statistical difference between the two groups located within $20 \mathrm{~km}$ and $30 \mathrm{~km}$ from the internal border, although not at greater distances.

\footnotetext{
${ }^{17}$ Tests of the equality of means for the latter three covariates are presented in Table 10.
} 
Figures 5 and 6 plot the outcome of interest, the average difference in the log of prices for millet and cowpea between markets located on either side of the Hausa-Zarma border. The average difference in the log of prices in Zarma markets relative to prices in Hausa markets are almost consistently higher, despite a strong seasonal variation, with prices in the Zarma region as much as 40 percent above those in Hausa regions. These plots suggest an unconditional border effect. Is this still evident when controlling for market-level observables?

Table 8 presents the results based on the RD design for the internal border effect for millet. Unlike the case for the Niger-Nigeria border, there are no markets located "arbitrarily close" to the border. Consequently, any theoretically valid and optimal bandwidth proposed for a typical RD analysis is not feasible for our empirical setting. Nevertheless, for markets within $20 \mathrm{~km}$ and $30 \mathrm{~km}$ (which, in our empirical setting, is practically close) to the ethnic border, we find statistically significant border effects. ${ }^{18}$ Our results in Table 8 confirm the internal border effect for millet, with millet prices increasing by about 21 percent if the market could be potentially relocated from Hausa to Zarma areas (Column 1). The difference in ethnicity seems to create a substantial transaction cost (or a barrier to trade) at the border. These results are robust to the inclusion of other covariates that could affect price changes, as well as controlling for monthly time effects and the latitude and longitude for the market's location (Column 2). They are also robust to comparing markets located within a $30-\mathrm{km}$ radius on either side of the border, suggesting that prices change by 26 percent at the internal border. As a falsification check, we find no evidence of an ethnic border effect when we restrict attention to markets located at least $100 \mathrm{~km}$ away from the border, or when we use the full sample. $^{19}$

\footnotetext{
${ }^{18}$ In the case of markets within 20 and $30 \mathrm{~km}$ in Table 9, we were unable to include the "distance" or its interaction with the "border" variable in the cowpea regressions due to numerical problems incurred in estimation, possibly due to rather limited variation in this "distance" variable for cowpea markets.

${ }^{19}$ Because there are no markets located arbitrarily close to the ethnic border in our empirical setting, using markets located within 20 or 30 kilometers could potentially bias the border effect. For markets located father away from the border, the border indicator is likely to just become an indicator variable for ethnicity, representing the ethnic difference rather than the difference at the ethnic
} 
The results for cowpea (Table 9) are also consistent with those for millet; cowpea prices change by 22 percent at the internal border (Column 1) and are robust to the inclusion of both timeinvariant and time-variant covariates and monthly time effects (Column 2). The effect is slightly higher for markets located within $30 \mathrm{~km}$ of the internal border (Columns 3 and 4), but there is no effect for markets located at least $100 \mathrm{~km}$ away from the border or for the full sample.

The internal border effect and the international border effect are similar in magnitude. The barriers to market integration between the Hausa and Zarma regions of Niger therefore appear to be at least as great as those imposed by the international border with Nigeria. The deadweight losses in foregone internal trade may correspondingly be of a similar order of magnitude.

\subsection{Potential Explanations of the Internal Ethnic Border Effect}

The results in Section 5 show that ethnicity can mitigate the economic effects of national boundaries and, at the same time, as shown in Section 6.1, create intra-national market segmentation in Niger. What mechanisms account for these effects? Table 7 suggests that differences in observed covariates at the market level are not driving the price change at the ethnic border. Nevertheless, it may be the case that ethnic differences serve as a proxy for other effects. For example, although French is the national language of Niger, it is not commonly spoken outside of urban areas; therefore, we could imagine that linguistic differences could serve as a barrier to negotiation or bargaining between the two groups. Alternatively, there could be institutional differences at the village or market level that are vestiges of differences in colonial treatment of the Hausa and Zarma regions or the provision of public services. Furthermore, underlying ethnic hostilities could reduce traders' willingness to trade with members of another ethnic group, even if they are geographically

border. As a falsification check, we deliberately select markets located more than 100 kilometers from the ethnic border and reestimate equation (2). If we find a statistically significant "border effect," our previous results in Columns 1 to 4 could have alternative explanations, such as ethnic differences instead of the differences at the ethnic border. Our results in Columns 5 and 6 confirm no "border effect." Furthermore, we re-estimate the model (equation 2) using the full sample, and do not find any "border effect" when there should be none. As the border effect cannot be falsified by using markets father away from the border, this suggests that our choice of markets near but not arbitrarily close to the ethnic border is not a source of bias. 
close to one another. Finally, social networks based on trust may play an important role in supporting intertemporal trade in credit and insurance, especially when formal institutions are weak or absent. In this case, the barrier in question is not fundamental cultural differences across ethnic groups, but rather a reflection in differences in trust associated with members of a similar group. We provide suggestive evidence of each of these mechanisms below.

\section{Differentials in Public Services, Taxes, and Trade Associations Between the Hausa and}

\section{Zarma Regions}

Table 10 presents results for tests of the equality of means for market-level characteristics along the ethnic border. All markets along the border impose market taxes, and there is no statistically significantly difference between the tax levels across markets $(0.17 \mathrm{CFA} / \mathrm{kg})$. Similarly, markets in both Hausa and Zarma regions have police controls surrounding the market, most notably on the market day. While the number of police controls is slightly higher in Hausa markets along the ethnic border, there is not a statistically significant difference between the two. Thus, it does not appear as if trade-related transaction costs are driving the border effect.

Differential investments in Hausa and Zarma regions do not seem to explain the ethnic border effect. There is not a statistically significant difference in road quality in markets near the border, nor in the number of credit institutions located in border markets. There is also no statistically significant difference in the traders' membership in trade associations; approximately $1 / 3$ of traders operating on markets in Zarma regions and 1/2 of traders operating in Hausa markets are members of trade associations, without a statistically significant difference between the two. Finally, traders operating on either side of the ethnic border have similar educational backgrounds, with less than 3.5 years of schooling.

\section{Complete Market Segmentation between Hausa and Zarma Markets}


Pervasive market segmentation does not appear to be a major driving force of the internal border effect. While time-series data on trade quantities are not available, over 50 percent of traders operating on the border markets have similar marketing characteristics: both groups search in a similar number of markets, have similar purchase and sales patterns, and a strong majority of traders in both markets have never changed their principal market. When looking at the direction of trade flows, a strong proportion of traders (over 85 percent) trade in markets located across the ethnic border. This shows that trade in millet and cowpeas occurs between these two ethnic regions, and that the absence of trade does not appear to be the reason for the border effect.

\section{Linguistic differences across regions}

At first glance, linguistic differences might be seen as an important contributing factor to the border effect, as none of the Hausa traders in the border markets speak Zarma, whereas at least 20 percent of Zarma traders speak Hausa. Yet fluency in a common language is not required for trade in these homogenous products. Interviews conducted by Aker with grain traders suggest that price and quantity negotiations between Hausa and Zarma traders can be conducted with a very low level of linguistic proficiency. A rudimentary knowledge of simple product terms and numbers in either language is sufficient for conducting negotiations and finalizing a sale. This suggests that despite the differences in the Hausa and Zarma languages, linguistic differences do not create a significant transaction cost to trade, and are therefore not the major source of the ethnic border effect.

If these mechanisms do not seem to be able to account for the ethnic border effect, are there other reasonable explanations? We next turn to two possible mechanisms that we feel are important. These reflect the role of gender and the importance of social networks in agricultural trade in Niger. 


\section{The Role of Culture: Gender and Trade}

Males represent a majority of traders in agricultural trade in Niger, representing almost 90 percent of all traders. But there is a stark difference in the gender composition between the Hausa and Zarma regions. In the restricted sample of markets located within $50 \mathrm{~km}$ of the Hausa-Zarma border, 30 percent of traders operating on the market in Zarma are female, as compared with only 5 percent in the Hausa markets. This difference in gender composition remains when using the entire sample, with the percentage of female traders increasing when moving farther west into Zarma regions, and decreasing when moving farther east into Hausa regions. ${ }^{20}$

The cultural difference in gender roles, as reflected by the gender composition of Zarma and Hausa markets, may be one source of the ethnic border effect if male Hausa traders are unwilling to trade with female traders in Zarma markets. This reticence could reduce the optimal quantity traded between those markets - effectively segmenting the markets and creating a border effect.

\section{Ethnicity in Social Networks and Access to Credit}

The credit market in Niger for the formal and informal sector is far from perfect: Fewer than 30 percent of households have access to formal financial services, with less than 15 percent having any form of financial savings with banking institutions. While approximately 50 percent of grain markets near the ethnic border have "credit institutions," these are often informal in nature and do not provide financing for grain-trading activities.

Traders often require financial services to pre-finance their purchases or to respond to fluctuating supply and demand. According to the trader panel survey, 40 percent of grain traders obtain loans for their business operations, with a higher percentage taking loans immediately after

\footnotetext{
${ }^{20}$ The difference in women's market participation between the two ethnic groups does not suggest that women cannot have a leadership role in Hausa culture. For example, there is a strong tradition of "Sarraounia" in the Hausa tradition - meaning "queen" or "female chief" - which is female leadership. In the Bagagi region of Niger, the title Sarraounia refers to a lineage of women from among whom was selected, through a specific ritual (Tarkama), a female leader who exercised both noncentralized political power and religious authority (Tidjani Alou 2009).
} 
the harvest period (Table 10). Similarly, over 30 percent buy or sell their commodity on credit. When asked about the source of their trade-related loans, such as formal financial institutions, friends, family or fellow traders, nearly 25 percent of traders stated that they borrow from other traders. While our data do not provide detailed information on the ethnic composition of traders' social networks, traders often borrow from other traders operating within the same market, and by association the same ethnic group. The ethnic border within Niger may therefore reflect, at least in part, the prevalence of credit market imperfections and the resulting reliance upon borrowing and lending within ethnic groups.

Interpersonal networks, ethnicity and credit are closely linked within Niger. More broadly, the interaction between trust, trade and ethnicity has long been recognized (Fafchamps 2000). While sociologists have emphasized that African entrepreneurs prefer to do business with members of their own ethnic group (Macharia 1988, Himbara 1994), economists have emphasized the role of trust in creating an enabling environment for trade (Mitchell 1969, Coleman 1988, Greif 1993, Platteau 1994). In particular, ethnicity may influence the allocation of credit in a number of ways, including a preference for discrimination (Becker 1971, Akerlof 1985), erroneous expectations (Yinger 1998), communication difficulties (Loury 1998), statistical discrimination (Arrow 1972, Coate and Loury 1993) and network effects (Saloner, 1985, Montgomery, 1991, Taylor 2000). In the context of imperfect credit markets, where firms and traders cannot assess the unobservable characteristics of traders and clients, social networks can play an important role in circulating information about credit histories and other attributes of relevance to potential trade partners. Additionally, membership in the same ethnic group may offer a means of recourse for nonpayment that does not exist for transactions between members of different ethnic groups. 


\section{Conclusion}

An understanding of the sources of market segmentation and market integration are particularly important for low income countries where efficiency gains from trade may have their largest impacts. The results in this paper show that an international border effect exists between Niger and Nigeria, although the magnitude of this effect is much smaller than what has been found in industrialized countries. Furthermore, the evidence suggests greater international integration between markets that share a common ethnicity. Results presented in this paper on the relatively minimal international border effect (as compared to what has been found for industrial countries) suggests that existing regional economic commissions may have been somewhat successful in promoting cross-border trade, even across currency areas or, alternatively, that longstanding trade routes- namely the one that links the Hausa of Northern Nigeria and Niger - continue to influence current-day market integration. ${ }^{21}$

Results presented in this paper on the role of ethnicity and market integration work both ways; not only does a common ethnicity promote international market integration between Niger and Nigeria, but also distinct ethnicities segment markets within Niger. This appears to be driven by social cleavages with respect to women's roles in trade, as well as by social networks that have been used to replace missing markets in Niger, namely in the area of credit and insurance. In such situations, ethnic borders may map the geography of trade more effectively than international borders do.

\footnotetext{
${ }^{21}$ A third hypothesis figures prominently in African studies. Herbst (2000) argues that since the colonial period, the powers that have ruled African capital cities have made mutual bargains not to threaten each other's periphery, and that the international relations regime has acquiesced by conferring de jure status on whomever controls the capital city. Thus weak states with porous and nondefended borders are a political equilibrium.
} 


\section{Bibliography}

Akerlof, G.A. 1985. "Discriminatory, status-based wages among tradition-oriented, stochastically trading coconut producers." Journal of Political Economy 93(2): 265-276.

Alesina, Alberto, R. Baqir and William Easterly. 1999. "Public Goods and Ethnic Divisions" The Quarterly Journal of Economics, November 1999,Vol. CXIV, Issue 4, pp. 1243-1284.

Alesina, Alberto and Eliana La Ferrara, 2000. "Participation In Heterogeneous Communities." The Quarterly Journal of Economics. 115(3): 847-904.

Anene, J. C.. 1970. The International Boundaries of Nigeria 1885-1960 (New York: The Humanities Press).

Araujo-Bonjean, Catherine, Magali Aubert, and Jonhy Egg. 2008. "Commerce du Mil en Afrique de l'Ouest: Les Frontières Abolies?" Paper prepared for CERDI Conference on "Intégration des Marchés et Sécurité Alimentaire dans les Pays en Développement, 3-4 November, Université d'Auvergne, Clermont-Ferrand, France.

Arrow, K.J. 1972. "Models of job discrimination.” In: Pascal, A.H. Ed., Racial Discrimination in Economic Life. Heath, Lexington, MA.

Asiwaju, A. I., ed. (1985), Partitioned Africa : Ethnic Relations Across Africa's International Boundaries, 1884-1984 (New York : St. Martin's Press).

Azam, Jean-Paul. 2007. Trade, Exchange Rate and Growth in Sub-Saharan Africa Cambridge, UK: Cambridge University Press.

Becker, G.S. 1971. The Economics of Discrimination. The University of Chicago Press, Chicago.

Ceglowski, Janet, 2003, “The Law of One Price: Intranational Evidence for Canada,” Canadian Journal of Economics, vol. 36, no. 2, pp. $373-400$.

Charlick, Robert 1991, Niger: Personal Rule and Survival in the Sahel, Westview Press: Boulder, Colorado.

Coate, S. and G.C. Loury. 1993. "Will affirmative action policies eliminate negative stereotypes?” American Economic Review 83(5): 1220-1240.

Coleman, J.S., 1988. "Social capital in the creation of human capital." American Journal of Sociology 94: S95-S120.

Daubrée, C. 1995. Marchés Parallèles et Equilibres Economiques: Expériences Africaines. Paris: L'Harmattan.

Engel, Charles and John Rogers, "How Wide is the Border?" American Economic Review, Dec. 1996, vol. 86 , no. 5 , pp. $1112-1125$. 
Easterly, William and Ross Levine (1997) “Africa's Growth Tragedy: Policies and Ethnic Divisions." Quarterly Journal of Economics. v112:4, p1203-50.

Fafchamps, Marcel. 2000. "Ethnicity and credit in African manufacturing." Journal of Development Economics. 61: 205-235

Fafchamps, Marcel and Flore Gubert. 2007. "The Formation of Risk Sharing Networks.” Journal of Development Economics. 83(2): 326-50.

Feyrer, James, "Trade and Growth - Exploiting the Time Series Dimension,” mimeo, Dartmouth College Economics Department, December 2008.

Frankel, Jeffrey and David Romer, "Does Trade Cause Growth?” American Economic Review, vol. 89, no. 3, 1999, pp. $379-399$.

Gopinath, Gita, Pierre-Olivier Gourinchas, Chang-Tai Hsieh, and Nicholas Li, 2009, "Estimating the Border Effect: Some New Evidence," mimeo.

Gorodnichenko, Yuriy, and Linda Tesar, 2009, "Border Effect or Country Effect? Seattle May Not Be So Far from Vancouver After All," American Economic Journal: Macroeconomics, Vol. 1, no. 1, January 2009, pp. $219-241$.

Greif, A., 1993. Contract enforceability and economic institutions in early trade: the Maghribi traders' coalition. American Economic Review 83(3): 525-548.

Hashim, Yahaya and Kate Meagher. 1999. Cross-Border Trade and the Parallel Currency Market: Trade and Finance in the Context of Structural Adjustment. A Case Study from Kano, Nigeria, Nordiska Afrikainstitutet Research Report No. 113, Sweden.

Herbst, Jeffrey, 200. States and Power in Africa: Comparative Lessons in Power and Control, Princeton University Press, Princeton, NJ.

Himbara, D., 1994. The failed Africanisation of commerce and industry in Kenya. World Development 22(3): 469-482.

Imbens, Guido and Thomas Lemieux. (2008), "Regression Discontinuity Designs: A Guide to Practice," Journal of Econometrics 142(2): 615-35.

Loury, G.C. 1998. "Discrimination in the post-civil rights era: beyond market interactions." Journal of Economic Perspectives. 12(2): 117-126.

Lovejoy, P. 1980. Caravans of Kola: The Hausa Kola Trade, 1700-1900. Zaria: Ahmadu Bello University Press.

Macharia, K., 1988. "Social networks: ethnicity and the informal sector in Nairobi." Institute for Development Studies, University of Nairobi, Nairobi, Working Paper No. 463.

Mauro, Paolo. 1995. “Corruption and Growth.” The Quarterly Journal of Economics. 110(3); 681-712. 
Miles, William F. S. 1994. Hausaland Divided: Colonialism and Independence in Nigeria and Niger. Ithaca: Cornell University Press.

Miles, William F. S. 2005. "Development, not Division: Local versus External Perceptions of the Niger-Nigeria." The Journal of Modern African Studies. 43:2:297-320 Cambridge University Press.

Mitchell, J. Clyde, ed., 1969. Social Networks in Urban Situations, Manchester University Press, Manchester, U.K..

Montgomery, J.D., 1991. "Social networks and labor-market outcomes: toward an economic analysis." American Economic Review 81(5): 1408-1418.

Oyejide, A., O. Ogunkola and A. Bankole. 2005. "Import Prohibition as a Trade Policy Instrument: The Nigerian Experience," In P. Gallagher, P. Low and A. Stoler, eds, Managing the Challenges of WTO Participation: 45 Case Studies. Cambridge, UK: Cambridge University Press.

Parsley, David, and Shang-Jin Wei. 2001. "Explaining the Border Effect: The Role of Exchange Rate Variability, Shipping Costs, and Geography," Journal of International Economics, vol. 55, pp. $87-105$.

Platteau, J., 1994. "Behind the market stage where real societies exist: Part II. The role of moral norms." Journal of Development Studies 30(4): 753-815.

Saloner, G., 1985. Old boy networks as screening mechanisms. Journal of Labor Economics 3(3): pp. 255-267.

Taylor, C.R., 1997. "The old-boy network and the young-gun effect." International Economic Review, Vol. 41, no. 4, November.

Tidjani Alou, Antoinette. 2009. "Niger and Sarraounia: One Hundred Years of Forgetting Female Leadership." Research in African Literatures. 40(1): 1527-2044.

United Nations Development Program. 2009. Human Development Report 2007/2008: Fighting Climate Change: Human Solidarity in a Divided World. New York, NY: UNDP.

Yinger, John, 1998. Evidence on Discrimination in Consumer Markets, Journal of Economic Perspectives, vol. 12, No. 2, pp. 23-40 


\section{Figure 1. International Borders and Ethnic Groups in Niger and northern Nigeria}

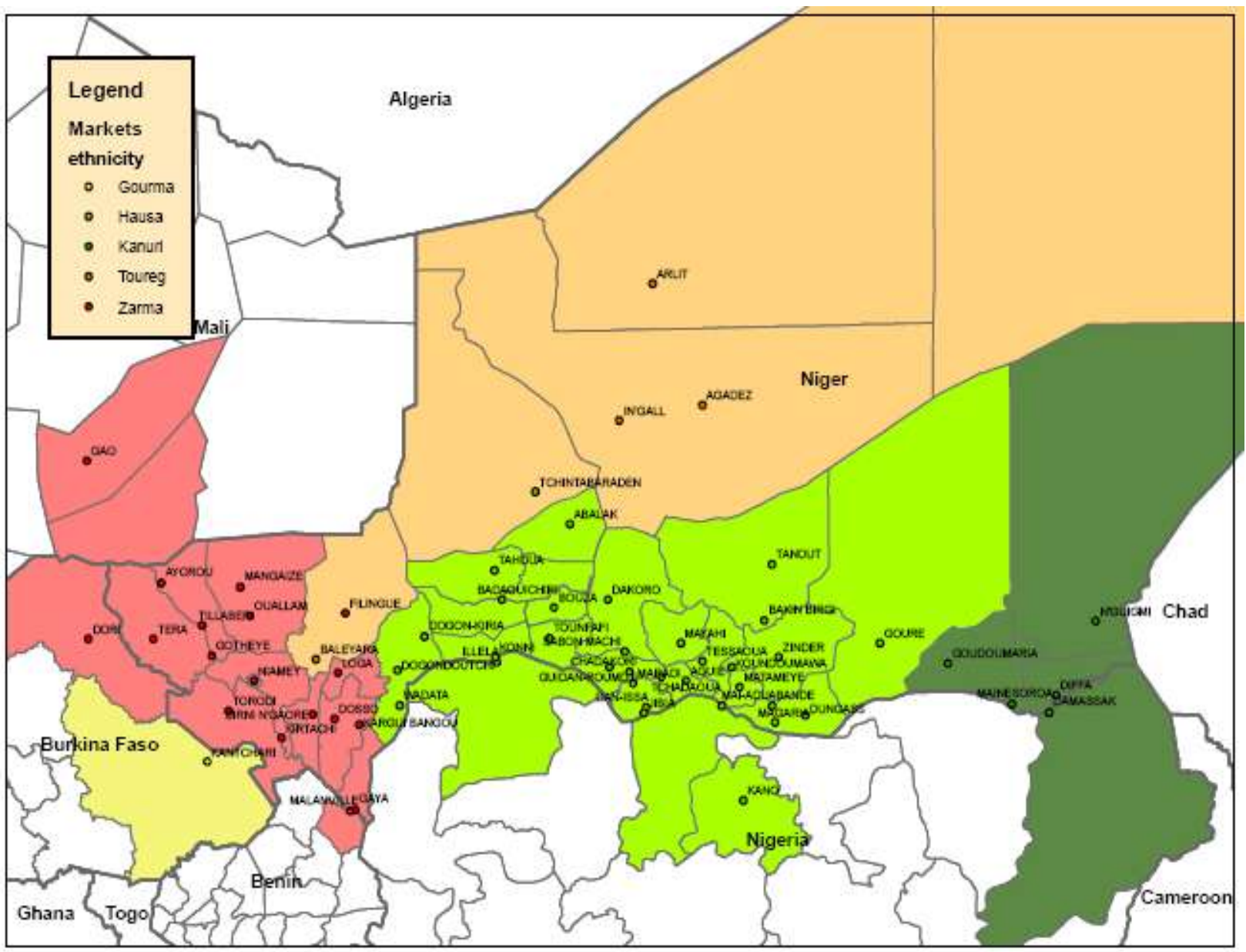

Notes: A map of the current ethnic and international borders for Benin, Burkina Faso, Mali, Niger and Nigeria, as well as the geographic location of major grain markets in these countries. Each color reflects the geographic location of different ethnic groups within Niger and surrounding countries. As currently drawn, the ethnic boundaries appear to correspond to administrative (departmental) boundaries, which is not the case; in most cases the ethnic boundary is located within a particular department. Nevertheless, the map shows the general geographic locations of each group. Ethnic boundaries created from the authors' household and trader-level data collected between 2005-2007. 
Figure 2. Average Difference in the Log of Millet Prices: Difference=Niger-Nigeria

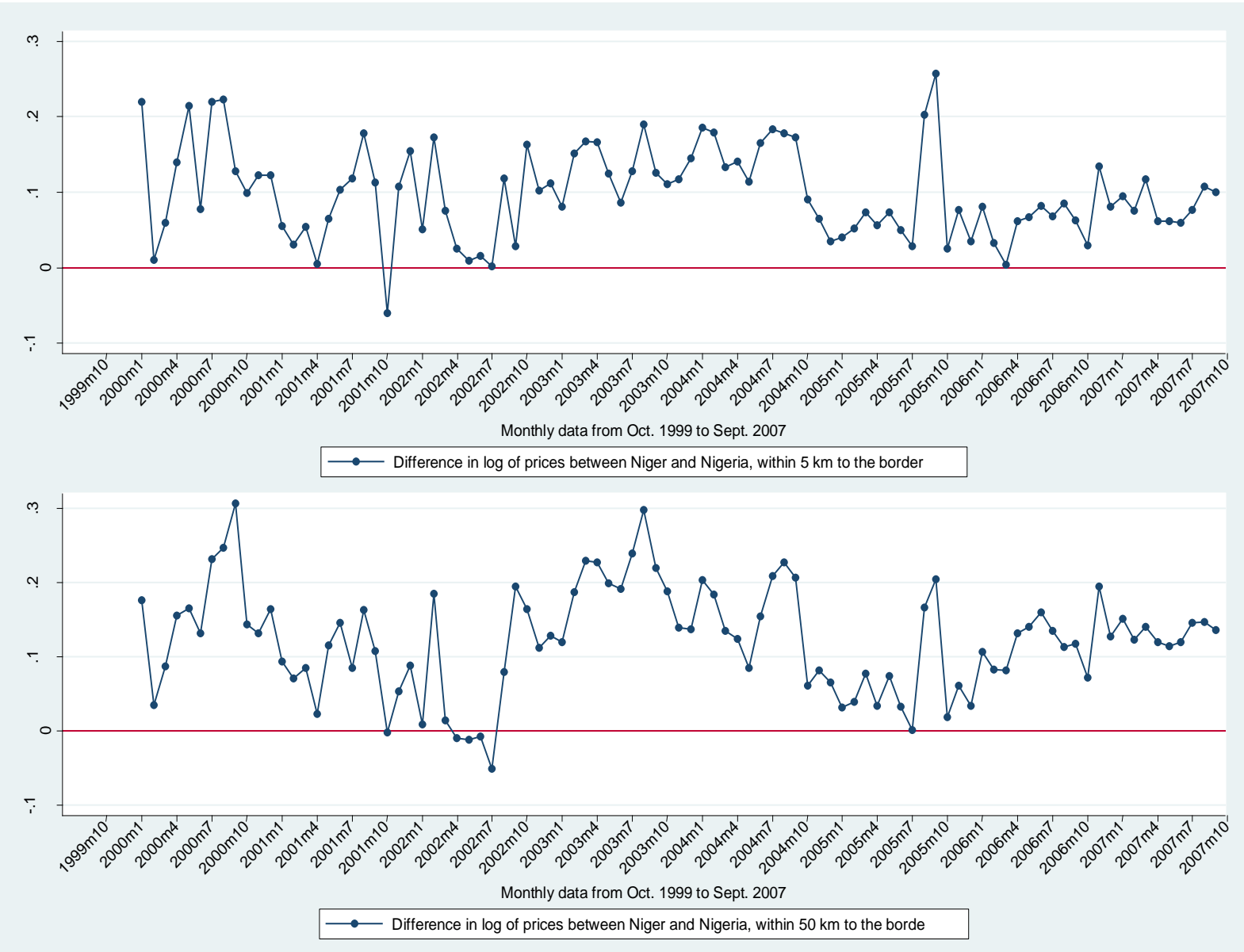


Figure 3. Average Difference in the Log of Cowpea Prices: Difference=Niger-Nigeria

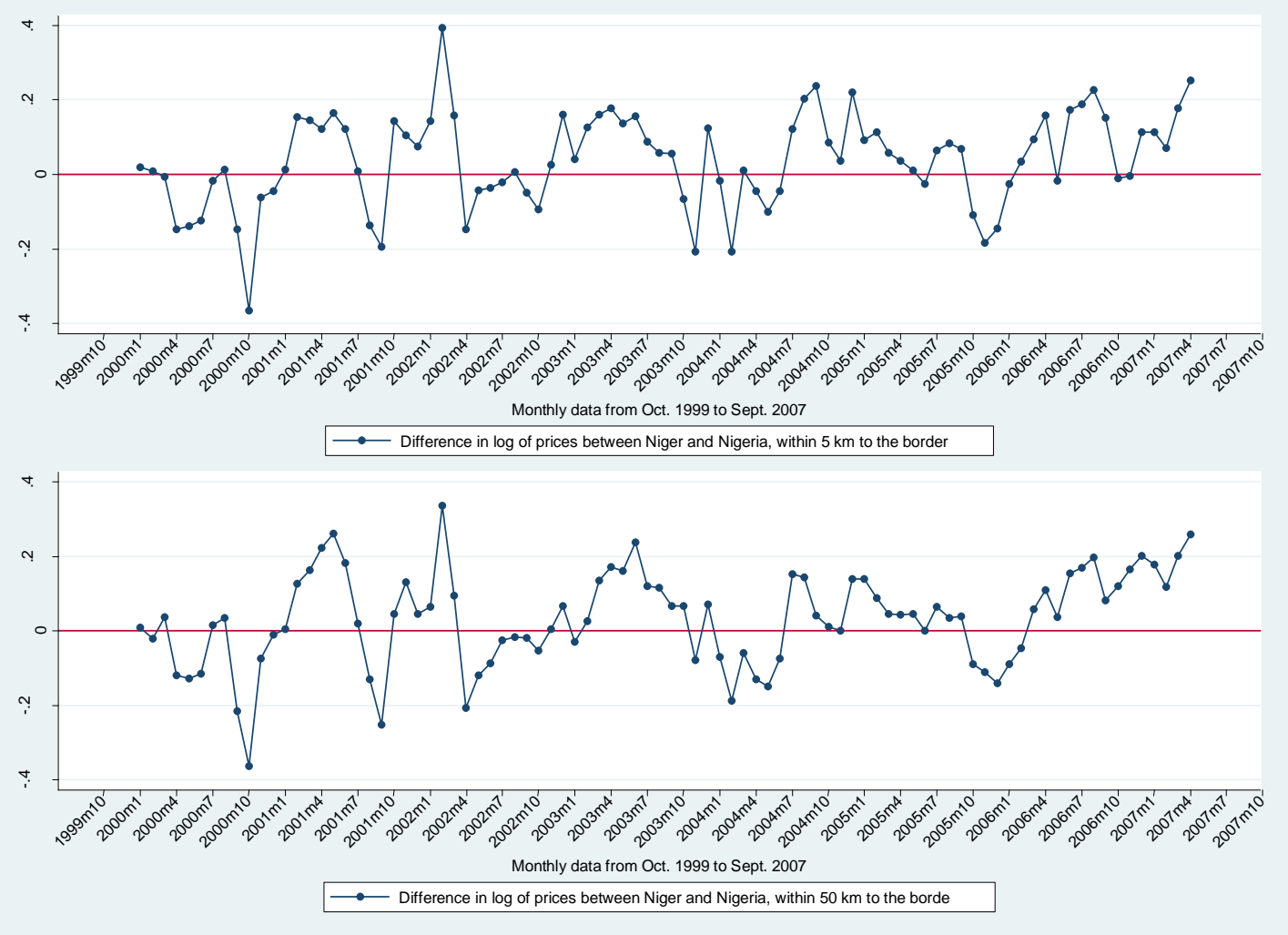


Figure 4. Kernel Distributions for Millet and Cowpea Prices
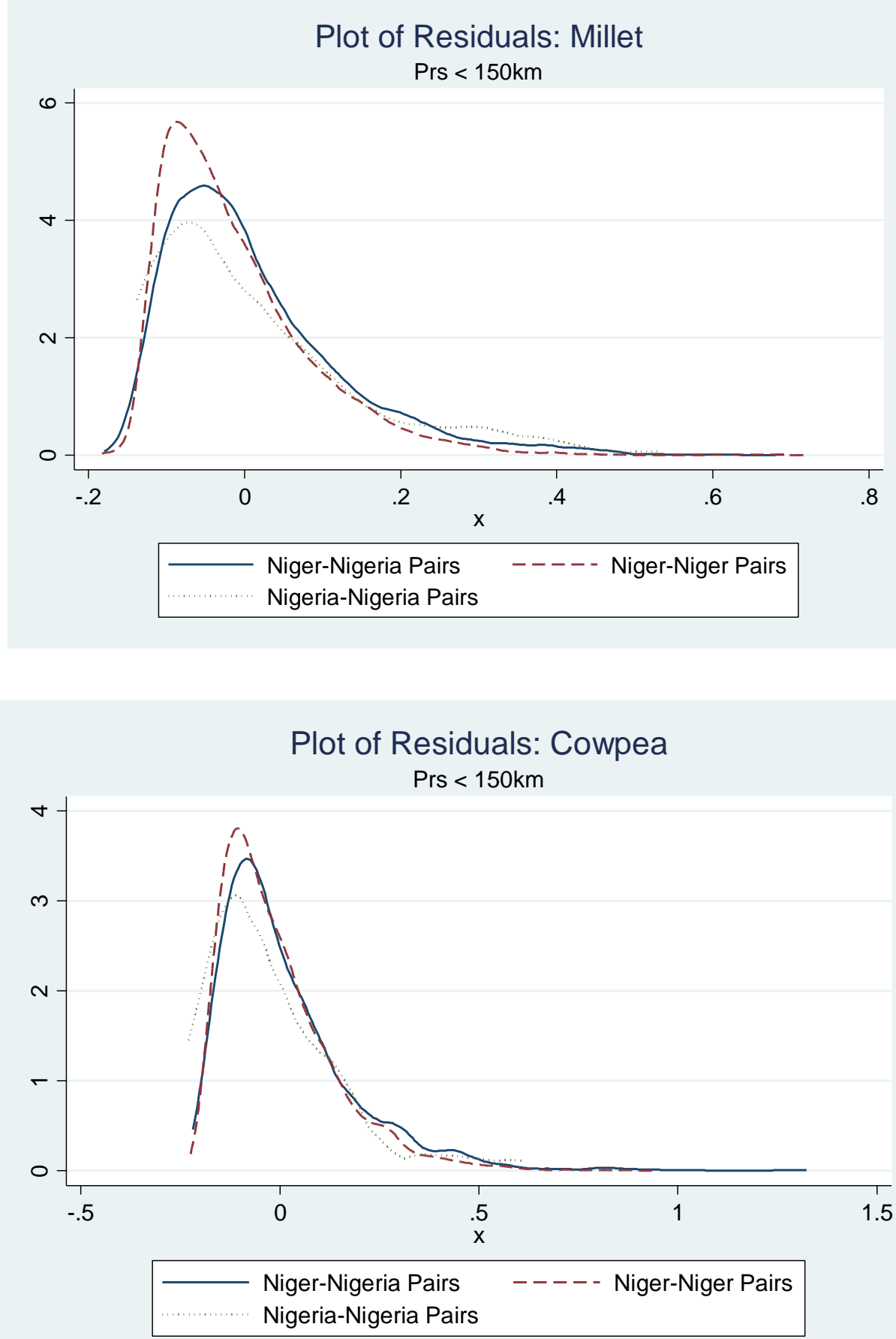
Figure 5. Average Difference in the Log of Millet Prices: Difference=Zarma-Hausa
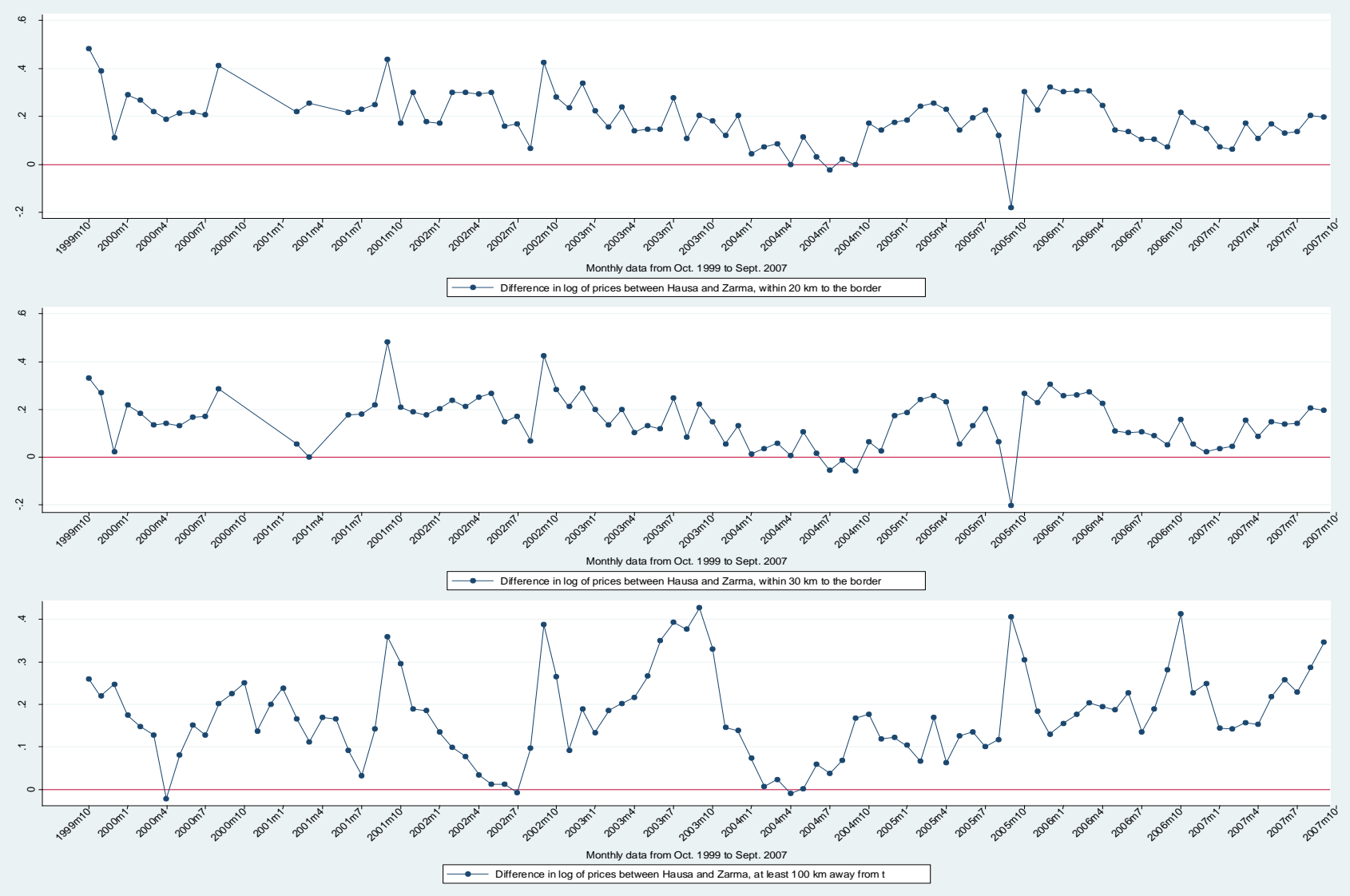
Figure 6. Average Difference in the Log of Cowpea Prices: Difference=Zarma-Hausa
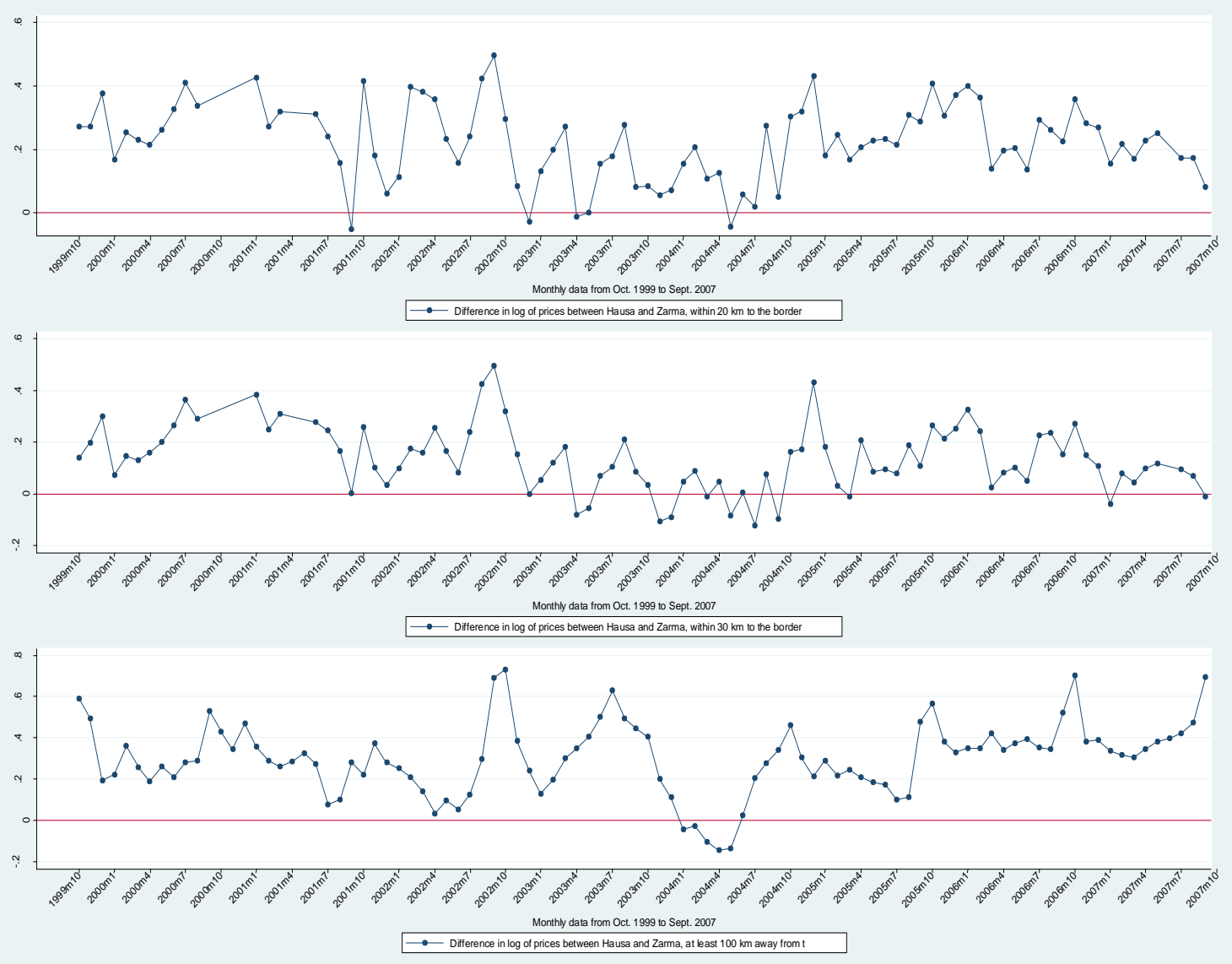
Table 1. Comparison of Observables by Country (Niger-Nigeria)

\begin{tabular}{|c|c|c|c|}
\hline \multirow[b]{2}{*}{ Observables } & \multicolumn{2}{|c|}{ Unconditional Mean } & \multirow{2}{*}{$\begin{array}{c}\begin{array}{c}\text { Difference in } \\
\text { Means }\end{array} \\
\begin{array}{c}\text { Unconditional } \\
\text { s.e. }\end{array} \\
\end{array}$} \\
\hline & $\begin{array}{c}\text { Market Pairs } \\
\text { within Niger } \\
\text { Mean (s.d.) }\end{array}$ & $\begin{array}{c}\text { Market Pairs } \\
\text { within Northern } \\
\text { Nigeria } \\
\text { Mean (s.d.) } \\
\end{array}$ & \\
\hline \multicolumn{4}{|l|}{ Panel A. Market Pair Level Data } \\
\hline Distance between markets $(\mathrm{km})$ & $375.29(207)$ & $369(271)$ & $5.38(65)$ \\
\hline Road Quality between markets & $.37(.49)$ & $.6(.52)$ & $-.22(.16)$ \\
\hline Cell Phone Coverage (2007) & $.89(.32)$ & $.6(.52)$ & $.29 *(.16)$ \\
\hline $\begin{array}{l}\text { Transport Costs between Markets } \\
(\mathrm{CFA} / \mathrm{kg})\end{array}$ & $12.35(6.72)$ & $12.19(6.67)$ & $.16(.22)$ \\
\hline Panel B. Market Level Data & Niger & Nigeria & \\
\hline Millet Price level (CFA/kg) & $124.33(33)$ & $112.96(31)$ & $11.60 * * *(1.83)$ \\
\hline Cowpea Price Level (CFA/kg) & 173(56) & $176(56)$ & $-3.21(3.36)$ \\
\hline \multicolumn{4}{|l|}{ Ethnic composition of traders } \\
\hline Hausa & $.58(.51)$ & $.8(.447)$ & '-.21(.21) \\
\hline Zarma & $.29(.464)$ & 0 & $.29 * * *(.096)$ \\
\hline Kanuri & $.08(.27)$ & $.2(.447)$ & $-.12(.19)$ \\
\hline Road Quality to Market & $.71(.46)$ & $.75(.5)$ & $.041(.25)$ \\
\hline Market Size & $105.08(90)$ & $176.75(149)$ & '-71.66(69) \\
\hline Cell Phone Coverage (2007) & $.95(.020)$ & $.8(.447)$ & $.158(.19)$ \\
\hline Drought between 1999-2007 & $.027(.162)$ & $.025(.156)$ & $.002(.007)$ \\
\hline Urban center $(>=35,000)$ & $.35(.49)$ & $0.8(.45)$ & $.45 *(.21)$ \\
\hline
\end{tabular}

Notes: Data from secondary sources and the the Niger trader survey collected by one of the authors. In Panel B, "Niger" markets are those that are in Niger and within $250 \mathrm{~km}$ of the Nigerian border, and "Nigeria" markets are those markets in Nigeria and within $250 \mathrm{~km}$ of the border. Huber-White robust standard errors clustered by market pair-month (Panel A) and by market-month (Panel B) are in parentheses. * is significant at the $10 \%$ level, ** significant at the $5 \%$ level, *** is significant at the $1 \%$ level. Prices are deflated by the Nigerien Consumer Price Index. 
Table 2. International Border Effect using Market Pair Regressions

\begin{tabular}{|c|c|c|c|c|c|c|c|c|c|c|c|c|}
\hline \multirow[b]{2}{*}{ Dependent variable: $\left|\ln \left(P_{i t} / P_{j t}\right)\right|$} & \multicolumn{6}{|c|}{ Millet } & \multicolumn{6}{|c|}{ Cowpea } \\
\hline & (1) & (2) & (3) & (4) & (5) & (6) & (7) & (8) & (9) & (10) & (11) & (12) \\
\hline Niger-Nigeria border & $\begin{array}{c}.021 * * * \\
(.003)\end{array}$ & $\begin{array}{c}.025 * * * \\
(.003)\end{array}$ & $\begin{array}{c}.025 * * * \\
(.003)\end{array}$ & $\begin{array}{c}.032 * * * \\
(.007)\end{array}$ & $\begin{array}{c}.018 * * * \\
(.002)\end{array}$ & $\begin{array}{c}.044 * * * \\
(.007)\end{array}$ & $\begin{array}{l}.019 * * \\
(.009)\end{array}$ & $\begin{array}{c}.024 * * * \\
(.008)\end{array}$ & $\begin{array}{c}.024 * * * \\
(.008)\end{array}$ & $\begin{array}{c}.047 * * * \\
(.009)\end{array}$ & $\begin{array}{c}.033 * * * \\
(.008)\end{array}$ & $\begin{array}{c}.027 * * * \\
(.008)\end{array}$ \\
\hline Niger Market & & & $\begin{array}{c}.007 \\
(.008)\end{array}$ & & & & & & $\begin{array}{l}.022 * \\
(.012)\end{array}$ & & & \\
\hline Nigeria Market & & & & $\begin{array}{l}-.007 \\
(.008)\end{array}$ & & & & & & $\begin{array}{l}-.022 * \\
(.012)\end{array}$ & & \\
\hline ln (transport costs) & & $\begin{array}{c}0.05 * * * \\
(.003)\end{array}$ & $\begin{array}{c}0.05 * * * \\
(.003)\end{array}$ & $\begin{array}{c}0.05^{* * *} * \\
(.003)\end{array}$ & $\begin{array}{c}0.04 * * * \\
(.003)\end{array}$ & $\begin{array}{c}0.05 * * * \\
(.002)\end{array}$ & & $\begin{array}{l}.066^{* * * *} \\
(.004)\end{array}$ & $\begin{array}{l}.066 * * * \\
(.004)\end{array}$ & $\begin{array}{l}.066 * * * \\
(.004)\end{array}$ & $\begin{array}{l}.065 * * * \\
(.004)\end{array}$ & \\
\hline Intra-ethnic & & & & & & $\begin{array}{c}-.014 * * * \\
(.003)\end{array}$ & & & & & & $\begin{array}{l}-.003 \\
(.003)\end{array}$ \\
\hline Intra-ethnic*border & & & & & & $\begin{array}{c}-.019 * * * \\
(.007)\end{array}$ & & & & & & $\begin{array}{c}-.028 * * \\
(.011)\end{array}$ \\
\hline Constant & $\begin{array}{c}.141 * * * \\
(.005)\end{array}$ & $\begin{array}{l}.095 * * * \\
(.003)\end{array}$ & $\begin{array}{c}.052 * * * \\
(.006)\end{array}$ & $\begin{array}{c}.095 * * * \\
(.003)\end{array}$ & $\begin{array}{c}.038 * * * \\
(.006)\end{array}$ & $\begin{array}{c}.097 * * * \\
(.003)\end{array}$ & $\begin{array}{l}.276 * * * \\
(.000)\end{array}$ & $\begin{array}{c}.192 * * * \\
(.005)\end{array}$ & $\begin{array}{c}.170 * * * \\
(.011)\end{array}$ & $\begin{array}{c}.192 * * * \\
(.005)\end{array}$ & $\begin{array}{c}.102 * * * \\
(.013)\end{array}$ & $\begin{array}{l}.191 \\
(.005)\end{array}$ \\
\hline Other covariates & No & Yes & Yes & Yes & Yes & Yes & No & Yes & Yes & Yes & Yes & Yes \\
\hline Market-Specific Fixed Effects & No & No & No & No & Yes & No & No & No & No & No & Yes & No \\
\hline Monthly time dummy & Yes & Yes & Yes & Yes & Yes & Yes & Yes & Yes & Yes & Yes & Yes & Yes \\
\hline \# of observations & 23760 & 23760 & 23760 & 23760 & 23760 & 23760 & 22689 & 22689 & 22689 & 22689 & 22689 & 22689 \\
\hline Dyadic s.e. & 0.005 & 0.005 & 0.005 & 0.005 & 0.006 & 0.006 & 0.01 & 0.01 & 0.01 & 0.01 & 0.01 & 0.01 \\
\hline $\mathrm{R}^{2}$ & 0.0109 & 0.0505 & 0.1609 & 0.0831 & 0.2956 & 0.086 & 0.0761 & 0.1064 & 0.1066 & 0.1066 & 0.2724 & 0.1069 \\
\hline Joint effect (same) ethnicity & & & & & & $\begin{array}{c}-.033 * * * \\
(.007)\end{array}$ & & & & & & $\begin{array}{c}-.031 * * \\
(.010)\end{array}$ \\
\hline
\end{tabular}


Notes: Data from the Niger trader survey and secondary sources collected by one of the authors. Additional covariates include the presence of drought, mobile phone coverage and urban status. Intra-ethnic is equal to one if both markets in a pair have the same ethnic composition, 0 otherwise. All regressions are clustered by month to correct for spatial dependence between markets over time. $*$ is significant at the $10 \%$ level, ** significant at the $5 \%$ level, $* * *$ is significant at the $1 \%$ level. 
Table 3: RD Estimates of Niger-Nigeria Border Effect on Millet Price

\begin{tabular}{|c|c|c|c|c|c|c|c|c|c|c|c|c|}
\hline \multirow{2}{*}{$\begin{array}{l}\text { Dependent variable: } \\
\text { Log of millet price }\end{array}$} & \multicolumn{4}{|c|}{ Within $5 \mathrm{~km}$ to the Niger-Nigeria Border } & \multicolumn{4}{|c|}{ Within $50 \mathrm{~km}$ to the Niger-Nigeria Border } & \multicolumn{4}{|c|}{ Full Sample } \\
\hline & $(1)$ & $(2)$ & (3) & $(4)$ & $(5)$ & $(6)$ & $(7)$ & $(8)$ & $(9)$ & $(10)$ & $(11)$ & $(12)$ \\
\hline \multirow[t]{2}{*}{ Niger } & $0.225^{* * *}$ & $0.173 *$ & $0.238 * * *$ & $0.232 * * *$ & $0.168 * * *$ & $0.155^{* *}$ & $0.183 * *$ & $0.208 * * *$ & $0.089^{*}$ & $0.085^{*}$ & 0.068 & $0.138 * * *$ \\
\hline & $(0.035)$ & $(0.076)$ & $(0.041)$ & $(0.020)$ & $(0.048)$ & $(0.069)$ & $(0.083)$ & $(0.028)$ & $(0.045)$ & $(0.046)$ & $(0.061)$ & $(0.040)$ \\
\hline \multicolumn{13}{|l|}{ Distance to the } \\
\hline \multirow[t]{2}{*}{ Border } & $0.013 * * *$ & $0.019 * *$ & -0.007 & 0.013 & $0.030 * * *$ & $0.027 * *$ & 0.021 & $0.019 * * *$ & -0.000 & -0.000 & $-0.001 *$ & $-0.001 * *$ \\
\hline & $(0.001)$ & $(0.007)$ & $(0.011)$ & $(0.008)$ & $(0.006)$ & $(0.009)$ & $(0.014)$ & $(0.007)$ & $(0.000)$ & $(0.000)$ & $(0.001)$ & $(0.000)$ \\
\hline \multirow[t]{2}{*}{ Niger*Distance } & $-0.074 * * *$ & $-0.076^{* * *}$ & $-0.036^{*}$ & $-0.044 *$ & $-0.080 * * *$ & $-0.069 * *$ & $-0.061 * *$ & $-0.027 *$ & 0.001 & 0.001 & 0.002 & $0.001 *$ \\
\hline & $(0.008)$ & $(0.011)$ & $(0.018)$ & $(0.019)$ & $(0.019)$ & $(0.026)$ & $(0.024)$ & $(0.015)$ & $(0.001)$ & $(0.001)$ & $(0.001)$ & $(0.001)$ \\
\hline \multirow[t]{2}{*}{ Hausa } & & & & -0.013 & & & & 0.007 & & & & $-0.061 * * *$ \\
\hline & & & & $(0.019)$ & & & & $(0.015)$ & & & & $(0.014)$ \\
\hline \multirow[t]{2}{*}{ Hausa*Niger } & & & & -0.138 & & & & $-0.195^{* * *}$ & & & & $-0.116^{* * *}$ \\
\hline & & & & $(0.077)$ & & & & $(0.032)$ & & & & $(0.034)$ \\
\hline \multicolumn{13}{|l|}{ Composite Niger } \\
\hline Effect & & & & $(0.078)$ & & & & $(0.037)$ & & & & $(0.028)$ \\
\hline \multicolumn{13}{|l|}{ Composite Hausa } \\
\hline \multirow[t]{2}{*}{ Effect } & & & & $-0.151 *$ & & & & $-0.188 * * *$ & & & & $-0.177 * * *$ \\
\hline & & & & $(0.072)$ & & & & $(0.030)$ & & & & $(0.030)$ \\
\hline \multirow[t]{2}{*}{ Constant } & $4.729 * * *$ & $4.755 * * *$ & $3.569 * * *$ & $4.751 * * *$ & $4.743 * * *$ & $4.745 * * *$ & $3.163 * * *$ & $4.741 * * *$ & $4.685^{* * *}$ & $4.682 * * *$ & $3.935 * * *$ & $4.729 * * *$ \\
\hline & $(0.007)$ & $(0.014)$ & $(0.760)$ & $(0.011)$ & $(0.014)$ & $(0.016)$ & -0.632 & $(0.008)$ & $(0.011)$ & $(0.015)$ & $(0.499)$ & $(0.005)$ \\
\hline \multirow{3}{*}{$\begin{array}{l}\text { Time-variant } \\
\text { covariates } \\
\text { Time-invariant } \\
\text { covariates } \\
\text { Time effect } \\
\text { (monthly) }\end{array}$} & No & Yes & Yes & Yes & No & Yes & Yes & Yes & No & Yes & Yes & Yes \\
\hline & No & No & Yes & No & No & No & Yes & No & No & No & Yes & No \\
\hline & No & Yes & Yes & Yes & No & Yes & Yes & Yes & No & Yes & Yes & Yes \\
\hline Sample size & 625 & 625 & 625 & 625 & 1,304 & 1,304 & 1,304 & 1,304 & 4,017 & 4,017 & 4,017 & 4,017 \\
\hline
\end{tabular}




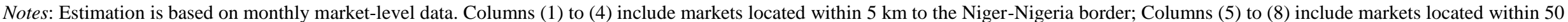

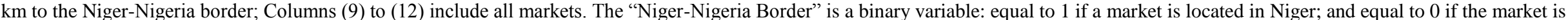

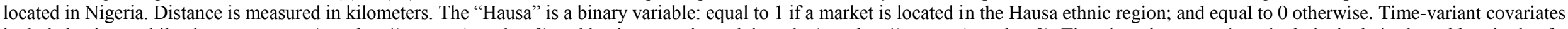

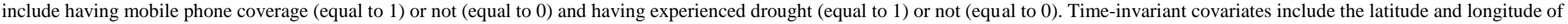

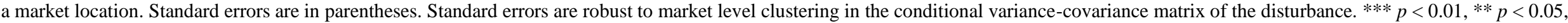

$* p<0.1$.

Table 4: RD Estimates of Niger-Nigeria Border Effect on Cowpea Price

\begin{tabular}{|c|c|c|c|c|c|c|c|c|c|c|c|c|}
\hline \multirow{2}{*}{$\begin{array}{l}\text { Dependent variable: } \\
\text { Log of cowpea price }\end{array}$} & \multicolumn{4}{|c|}{ Within $5 \mathrm{~km}$ to the Niger-Nigeria Border } & \multicolumn{4}{|c|}{ Within $50 \mathrm{~km}$ to the Niger-Nigeria Border } & \multicolumn{4}{|c|}{ Full Sample } \\
\hline & $(1)$ & $(2)$ & (3) & (4) & $(5)$ & $(6)$ & $(7)$ & $(8)$ & $(9)$ & $(10)$ & $(11)$ & $(12)$ \\
\hline \multirow[t]{2}{*}{ Niger-Nigeria Border } & $0.266 * * *$ & $0.195^{* *}$ & $0.202 * * *$ & $0.202 * * *$ & $0.279 * * *$ & $0.268 * * *$ & $0.214^{* *}$ & $0.278 * * *$ & 0.017 & 0.011 & -0.016 & $0.149 * *$ \\
\hline & $(0.048)$ & $(0.080)$ & $(0.051)$ & $(0.045)$ & $(0.048)$ & $(0.063)$ & $(0.092)$ & $(0.054)$ & $(0.070)$ & $(0.068)$ & $(0.069)$ & $(0.058)$ \\
\hline \multirow[t]{2}{*}{ Distance to the Border } & -0.020 & -0.008 & -0.032 & -0.033 & 0.005 & 0.002 & $0.037 * *$ & -0.031 & 0.000 & 0.000 & -0.001 & 0.000 \\
\hline & $(0.016)$ & $(0.011)$ & $(0.017)$ & $(0.018)$ & $(0.016)$ & $(0.017)$ & $(0.016)$ & $(0.023)$ & $(0.000)$ & $(0.000)$ & $(0.001)$ & $(0.000)$ \\
\hline Border*Distance & $(0.019)$ & $(0.014)$ & $(0.025)$ & $(0.018)$ & $(0.028)$ & $(0.033)$ & $(0.034)$ & $(0.031)$ & $(0.001)$ & $(0.001)$ & $(0.002)$ & $(0.001)$ \\
\hline \multirow[t]{2}{*}{ Hausa } & & & & -0.117 & & & & -0.092 & & & & 0.027 \\
\hline & & & & $(0.072)$ & & & & $(0.071)$ & & & & $(0.029)$ \\
\hline \multirow[t]{2}{*}{ Hausa*Border } & & & & -0.057 & & & & $-0.187^{*}$ & & & & $-0.239 * * *$ \\
\hline & & & & $(0.071)$ & & & & $(0.092)$ & & & & $(0.054)$ \\
\hline Composite Border Effect & & & & $0.144 * *$ & & & & 0.090 & & & & $-0.090 *$ \\
\hline \multirow[t]{2}{*}{ Composite Hausa Effect } & & & & $-0.175 * * *$ & & & & $-0.279 * * *$ & & & & $-0.213 * * *$ \\
\hline & & & & $(0.005)$ & & & & $(0.064)$ & & & & $(0.045)$ \\
\hline \multirow[t]{2}{*}{ Constant } & $5.050 * * *$ & $5.104 * * *$ & $3.799 * * *$ & $5.111 * * *$ & $5.070 * * *$ & $5.086 * * *$ & $4.921 * * *$ & $5.089 * * *$ & $5.120 * * *$ & $5.123 * * *$ & $4.498 * * *$ & $5.099 * * *$ \\
\hline & $(0.025)$ & $(0.034)$ & $(0.757)$ & $(0.021)$ & $(0.028)$ & $(0.027)$ & $(0.949)$ & $(0.015)$ & $(0.038)$ & $(0.026)$ & $(0.639)$ & $(0.009)$ \\
\hline Time-variant covariates & No & Yes & Yes & Yes & No & Yes & Yes & Yes & No & Yes & Yes & Yes \\
\hline Time-invariant covariates & No & No & Yes & No & No & No & Yes & No & No & No & Yes & No \\
\hline Time effect (monthly) & No & Yes & Yes & Yes & No & Yes & Yes & Yes & No & Yes & Yes & Yes \\
\hline Sample size & 563 & 563 & 563 & 563 & 1,247 & 1,247 & 1,247 & 1,247 & 3,862 & 3,862 & 3,862 & 3,862 \\
\hline
\end{tabular}


Notes: Estimation is based on monthly market-level data. Columns (1) to (4) include markets located within $5 \mathrm{~km}$ to the Niger-Nigeria border; Columns (5) to (8) include markets located within $50 \mathrm{~km}$ to the Niger-Nigeria border; Columns (9) to (12) include all markets. The "Niger-Nigeria Border" is a binary dummy variable: equal to 1 if a market is

located in Niger; and equal to 0 if the market is located in Nigeria. Distance is measured in kilometers. The "Hausa" is a binary dummy variable: equal to 1 if a market is located in the Hausa ethnic region; and equal to 0 otherwise. Time-variant covariates include having mobile phone coverage (equal to 1 ) or not (equal to 0 ) and having experienced

drought (equal to 1) or not (equal to 0). Time-invariant covariates include the latitude and longitude of a market location. Standard errors are in parentheses. Standard errors are robust to market level clustering in the conditional variance-covariance matrix of the disturbance. $* * * p<0.01, * * p<0.05, * p<0.1$. 
Table 5: Equality of Means for Market-Level Characteristics and the Niger-Nigeria Border

\begin{tabular}{|c|c|c|c|}
\hline $\begin{array}{l}\text { Dependent variable: Niger-Nigeria border dummy } \\
(=1 \text { in Niger; }=0 \text { in Nigeria) }\end{array}$ & (1) & (2) & (3) \\
\hline Having mobile phone coverage (1) or not (0) & $\begin{array}{l}0.487 * \\
(0.247)\end{array}$ & $\begin{array}{l}0.409 * * \\
(0.148)\end{array}$ & $\begin{array}{l}0.176^{*} \\
(0.103)\end{array}$ \\
\hline Having experienced drought (1) or not (0) & $\begin{array}{c}0.002 \\
(0.078)\end{array}$ & $\begin{array}{c}0.055 \\
(0.060)\end{array}$ & $\begin{array}{c}0.049 \\
(0.030)\end{array}$ \\
\hline Being an urban center $(1)$ or not $(0)$ & $\begin{array}{l}-0.524 \\
(0.295)\end{array}$ & $\begin{array}{l}-0.311 \\
(0.200)\end{array}$ & $\begin{array}{c}-0.263 * * \\
(0.119)\end{array}$ \\
\hline Constant & $\begin{array}{l}0.636 * * \\
(0.265)\end{array}$ & $\begin{array}{l}0.781 * * * \\
(0.141)\end{array}$ & $\begin{array}{l}0.927 * * * \\
(0.046)\end{array}$ \\
\hline Sample size & 768 & 1,536 & 4,512 \\
\hline
\end{tabular}

Notes: Estimation is based on monthly market-level data including monthly time effects. Column (1) includes markets located within $5 \mathrm{~km}$ to the Niger-Nigeria border; Column (2) includes markets located within $50 \mathrm{~km}$ to the NigerNigeria border; Column (3) includes all markets. The mobile phone coverage is measured at market level in each month. The drought variable for a market in a month equals 1: 1) if the market receives rainfall less than or equal to 2 standard deviations below its average rainfall level during the rainy season, or 2) if there are 15 consecutive days without rainfall during the rainy season; and equals 0 otherwise. The urban variable for a market equals 1 if the market is located in an urban center with at least 35,000 people; and equals 0 otherwise. Standard errors are robust to market level clustering in the conditional variance-covariance matrix of the disturbance. $* * * p<0.01, * * p<0.05, * p<0.1$. 
Table 6: Difference in Trader-Level Characteristics between Niger and northern Nigeria

\begin{tabular}{lcccccc}
\hline \hline & \multicolumn{2}{c}{ Niger } & \multicolumn{2}{c}{ Nigeria } & Coefficient & S.e. \\
& Mean & s.d. & Mean & S.d. & & \\
Trading Behavior & & & & & & \\
Number of markets followed & 4.35 & 3.90 & 5.29 & 2.21 & -0.93 & 0.84 \\
Number of market contacts & 4.24 & 3.89 & 5.00 & 5.59 & -0.76 & 2.12 \\
Number of purchase and sales markets & 4.36 & 2.85 & 5.38 & 1.92 & -1.01 & 0.68 \\
Trade in cross-border markets within a 50-km radius & 0.27 & 0.22 & 0.55 & 0.07 & $-0.28 * *$ & 0.05 \\
Quantity traded in 2005/2006 (kg) & 12936 & 59696 & 10025 & 14106 & -2911 & 36096 \\
Number of police controls & 3.80 & 0.90 & 4.00 & 1.00 & -0.17 & 0.69 \\
Market Size & 97.3 & 80.7 & 176.75 & 149 & -79.42 & 73.02 \\
\hline
\end{tabular}

Notes: Data from the Niger trader survey and secondary sources collected by Aker. N=415 traders, 37 markets. Huber-White robust standard errors are in parentheses. * is significant at the $10 \%$ level, ** significant at the $5 \%$ level, *** is significant at the $1 \%$ level. 
Table 7: Equality of Means for Market-Level Characteristics and the Hausa-Zarma Border

\begin{tabular}{|c|c|c|c|c|}
\hline $\begin{array}{l}\text { Dependent variable: Hausa-Zarma border dummy } \\
(=1 \text { in Zarma; }=0 \text { in Hausa) }\end{array}$ & (1) & (2) & (3) & (4) \\
\hline Having mobile phone coverage (1) or not (0) & $\begin{array}{l}0.524^{*} \\
(0.192)\end{array}$ & $\begin{array}{c}0.604 * * * \\
(0.119)\end{array}$ & $\begin{array}{l}-0.101 \\
(0.131)\end{array}$ & $\begin{array}{l}-0.028 \\
(0.109)\end{array}$ \\
\hline Having experienced drought (1) or not (0) & $\begin{array}{c}0.065 \\
(0.073)\end{array}$ & $\begin{array}{c}0.060 \\
(0.058)\end{array}$ & $\begin{array}{l}-0.043 \\
(0.066)\end{array}$ & $\begin{array}{l}-0.005 \\
(0.060)\end{array}$ \\
\hline Being an urban center $(1)$ or not $(0)$ & $\begin{array}{l}-0.003 \\
(0.558)\end{array}$ & $\begin{array}{l}-0.176 \\
(0.493)\end{array}$ & $\begin{array}{c}0.067 \\
(0.202)\end{array}$ & $\begin{array}{c}0.026 \\
(0.179)\end{array}$ \\
\hline Constant & $\begin{array}{l}0.280 \\
(0.287)\end{array}$ & $\begin{array}{c}0.419 \\
(0.256)\end{array}$ & $\begin{array}{l}0.276^{* *} \\
(0.112)\end{array}$ & $\begin{array}{c}0.353 * * * \\
(0.100)\end{array}$ \\
\hline Sample size & 480 & 576 & 2,592 & 3,552 \\
\hline
\end{tabular}

Notes: Estimation is based on monthly market-level data including monthly time effects. Column (1) includes markets located within $20 \mathrm{~km}$ to the Hausa-Zarma border; Column (2) includes markets located within $30 \mathrm{~km}$ to the HausaZarma border; Column (3) includes markets located at least $100 \mathrm{~km}$ away from the Hausa-Zarma border; Column (4) includes all markets. The mobile phone coverage is measured at market level in each month. The drought variable for a market in a month equals $1: 1$ ) if the market receives rainfall less than or equal to 2 standard deviations below its average rainfall level during the rainy season, or 2) if there are 15 consecutive days without rainfall during the rainy season; and equals 0 otherwise. The urban variable for a market equals 1 if the market is located in an urban center with at least 35,000 people; and equals 0 otherwise. Standard errors are robust to market level clustering in the conditional variance-covariance matrix of the disturbance. $* * * p<0.01, * * p<0.05, * p<0.1$. 
Table 8: RD Estimates of Hausa-Zarma Border Effect on Millet Price

\begin{tabular}{|c|c|c|c|c|c|c|c|c|}
\hline \multirow{2}{*}{$\begin{array}{l}\text { Dependent variable: } \\
\text { Log of millet price }\end{array}$} & \multicolumn{2}{|c|}{$\begin{array}{l}\text { Within } 20 \mathrm{~km} \text { to the } \\
\text { border }\end{array}$} & \multicolumn{2}{|c|}{$\begin{array}{l}\text { Within } 30 \mathrm{~km} \text { to the } \\
\text { border }\end{array}$} & \multicolumn{2}{|c|}{$\begin{array}{c}\text { At least } 100 \mathrm{~km} \text { away from the } \\
\text { border }\end{array}$} & \multicolumn{2}{|c|}{ Full Sample } \\
\hline & $(1)$ & $(2)$ & $(3)$ & (4) & (5) & $(6)$ & $(7)$ & $(8)$ \\
\hline Hausa-Zarma Border & $\begin{array}{c}0.212 * * * \\
(0.011)\end{array}$ & $\begin{array}{c}0.278 * * * \\
(0.053)\end{array}$ & $\begin{array}{c}0.173 * * * \\
(0.016)\end{array}$ & $\begin{array}{c}0.264 * * * \\
(0.036)\end{array}$ & $\begin{array}{l}-0.126 \\
(0.155)\end{array}$ & $\begin{array}{c}0.070 \\
(0.151)\end{array}$ & $\begin{array}{c}0.035 \\
(0.054)\end{array}$ & $\begin{array}{c}0.057 \\
(0.051)\end{array}$ \\
\hline Distance to the Border & $\begin{array}{c}-0.005 * * * \\
(0.001)\end{array}$ & $\begin{array}{c}0.000 \\
(0.002)\end{array}$ & $\begin{array}{c}-0.007 * * * \\
(0.001)\end{array}$ & $\begin{array}{l}-0.001 \\
(0.002)\end{array}$ & $\begin{array}{c}0.000 \\
(0.003)\end{array}$ & $\begin{array}{c}0.000 \\
(0.002)\end{array}$ & $\begin{array}{l}-0.000 \\
(0.001)\end{array}$ & $\begin{array}{c}-0.001 * * \\
(0.001)\end{array}$ \\
\hline Border*Distance & $\begin{array}{l}-0.002 * \\
(0.001)\end{array}$ & $\begin{array}{l}-0.007 \\
(0.005)\end{array}$ & $\begin{array}{l}0.005^{*} \\
(0.002)\end{array}$ & $\begin{array}{l}-0.005 \\
(0.005)\end{array}$ & $\begin{array}{c}0.000 \\
(0.006)\end{array}$ & $\begin{array}{l}-0.002 \\
(0.003)\end{array}$ & $\begin{array}{c}0.002 \\
(0.001)\end{array}$ & $\begin{array}{c}0.001 \\
(0.001)\end{array}$ \\
\hline Constant & $\begin{array}{c}4.791 * * * \\
(0.011)\end{array}$ & $\begin{array}{c}4.401 * * * \\
(0.406)\end{array}$ & $\begin{array}{c}4.808 * * * \\
(0.008)\end{array}$ & $\begin{array}{c}4.351 * * * \\
(0.068)\end{array}$ & $\begin{array}{c}4.972 * * * \\
(0.333)\end{array}$ & $\begin{array}{c}4.058 * * * \\
(0.633)\end{array}$ & $\begin{array}{c}4.817 * * * \\
(0.040)\end{array}$ & $\begin{array}{c}4.337 * * * \\
(0.375)\end{array}$ \\
\hline Distance-squared & No & No & Yes & Yes & Yes & Yes & Yes & Yes \\
\hline Distance-cubic & No & No & No & No & Yes & Yes & Yes & Yes \\
\hline Time-variant covariates & No & Yes & No & Yes & No & Yes & No & Yes \\
\hline Time-invariant covariates & No & Yes & No & Yes & No & Yes & No & Yes \\
\hline Time effect (monthly) & No & Yes & No & Yes & No & Yes & No & Yes \\
\hline Sample size & 333 & 333 & 420 & 420 & 2,408 & 2,408 & 3,206 & 3,206 \\
\hline
\end{tabular}

Notes: Estimation is based on monthly market-level data. Columns (1) and (2) include markets located within 20 km to the Hausa-Zarma border; Columns (3) and (4) include markets located within $30 \mathrm{~km}$ to the Hausa-Zarma border; Columns (5) and (6) include markets located at least $100 \mathrm{~km}$ away from the Hausa-Zarma border.

Columns (7) and (8) include all markets. The "Hausa-Zarma Border" is a binary dummy variable: equal to 1 if a market is located in Zarma; and equal to 0 if the market is located in Hausa. Distance is measured in kilometers. Time-variant covariates include having mobile phone coverage (equal to 1) or not (equal to 0) and having experienced drought (equal to 1 ) or not (equal to 0 ). Time-invariant covariates include the latitude and longitude of a market location. Standard errors are in parentheses. Standard errors are robust to market level clustering in the conditional variance-covariance matrix of the disturbance. $* * * p<0.01, * * p<0.05, * p<0.1$. 
Table 9: RD Estimates of Hausa-Zarma Border Effect on Cowpea Price

\begin{tabular}{|c|c|c|c|c|c|c|c|c|}
\hline \multirow{2}{*}{$\begin{array}{l}\text { Dependent variable: } \\
\text { Log of cowpea price }\end{array}$} & \multicolumn{2}{|c|}{$\begin{array}{l}\text { Within } 20 \mathrm{~km} \text { to the } \\
\text { border }\end{array}$} & \multicolumn{2}{|c|}{$\begin{array}{c}\text { Within } 30 \mathrm{~km} \text { to the } \\
\text { border }\end{array}$} & \multicolumn{2}{|c|}{$\begin{array}{c}\text { At least } 100 \mathrm{~km} \text { away from the } \\
\text { border }\end{array}$} & \multicolumn{2}{|c|}{ Full Sample } \\
\hline & $(1)$ & $(2)$ & $(3)$ & (4) & (5) & $(6)$ & $(7)$ & $(8)$ \\
\hline Hausa-Zarma Border & $\begin{array}{l}0.215^{* *} \\
(0.037)\end{array}$ & $\begin{array}{c}0.222 * * * \\
(0.004)\end{array}$ & $\begin{array}{c}0.256 * * * \\
(0.029)\end{array}$ & $\begin{array}{c}0.295 * * * \\
(0.003)\end{array}$ & $\begin{array}{c}0.151 \\
(0.136)\end{array}$ & $\begin{array}{l}-0.008 \\
(0.192)\end{array}$ & $\begin{array}{c}0.064 \\
(0.063)\end{array}$ & $\begin{array}{l}-0.071 \\
(0.088)\end{array}$ \\
\hline Distance to the Border & & & $\begin{array}{c}-0.012 * * \\
(0.002)\end{array}$ & $\begin{array}{c}-0.015 * * * \\
(0.001)\end{array}$ & $\begin{array}{l}-0.003 \\
(0.003)\end{array}$ & $\begin{array}{l}-0.003 * \\
(0.002)\end{array}$ & $\begin{array}{c}-0.002 * * \\
(0.001)\end{array}$ & $\begin{array}{c}-0.003 * * * \\
(0.001)\end{array}$ \\
\hline Border*Distance & & & & & $\begin{array}{c}0.008 \\
(0.006)\end{array}$ & $\begin{array}{c}0.003 \\
(0.004)\end{array}$ & $\begin{array}{c}0.004 * * * \\
(0.001)\end{array}$ & $\begin{array}{c}0.004 * * * \\
(0.001)\end{array}$ \\
\hline Constant & $\begin{array}{c}4.966 * * * \\
(0.000)\end{array}$ & $\begin{array}{c}5.721 * * * \\
(0.195)\end{array}$ & $\begin{array}{c}5.047 * * * \\
(0.015)\end{array}$ & $\begin{array}{c}3.184 * * * \\
(0.290)\end{array}$ & $\begin{array}{c}4.777 * * * \\
(0.310)\end{array}$ & $\begin{array}{c}6.032 * * * \\
(1.019)\end{array}$ & $\begin{array}{c}4.981 * * * \\
(0.035)\end{array}$ & $\begin{array}{c}6.105^{* * *} \\
(0.618)\end{array}$ \\
\hline Distance-squared & No & No & No & No & Yes & Yes & Yes & Yes \\
\hline Distance-cubic & No & No & No & No & Yes & Yes & Yes & Yes \\
\hline Time-variant covariates & No & Yes & No & Yes & No & Yes & No & Yes \\
\hline Time-invariant covariates & No & Yes & No & Yes & No & Yes & No & Yes \\
\hline Time effect (monthly) & No & Yes & No & Yes & No & Yes & No & Yes \\
\hline Sample size & 267 & 267 & 355 & 355 & 2,362 & 2,362 & 3,094 & 3,094 \\
\hline
\end{tabular}

Notes: Estimation is based on monthly market-level data. Columns (1) and (2) include markets located within 20 km to the Hausa-Zarma border; Columns (3) and (4) include markets located within $30 \mathrm{~km}$ to the Hausa-Zarma border; Columns (5) and (6) include markets located at least $100 \mathrm{~km}$ away from the Hausa-Zarma border.

Columns (7) and (8) include all markets. The "Hausa-Zarma Border" is a binary dummy variable: equal to 1 if a market is located in Zarma; and equal to 0 if the market is located in Hausa. Distance is measured in kilometers. Time-variant covariates include having mobile phone coverage (equal to 1) or not (equal to 0 ) and having experienced drought (equal to 1) or not (equal to 0). Time-invariant covariates include the latitude and longitude of a market location. Standard errors are in parentheses. Standard errors are robust to market level clustering in the conditional variance-covariance matrix of the disturbance. $* * * p<0.01, * * p<0.05, * p<0.1$. 
Table 10: Difference in Trader-Level Characteristics between Hausa and Zarma Regions

\begin{tabular}{|c|c|c|c|c|c|c|}
\hline & \multicolumn{2}{|c|}{ Zarma } & \multicolumn{2}{|c|}{ Hausa } & \multirow[t]{2}{*}{ Coefficient } & \multirow[t]{2}{*}{ S.e. } \\
\hline & Mean & s.d. & Mean & s.d. & & \\
\hline \multicolumn{7}{|l|}{ Demographic Characteristics } \\
\hline Years of Education & 2.18 & 2.70 & 3.05 & 2.56 & -0.88 & 0.60 \\
\hline Age & 43.20 & 13.40 & 44.10 & 11.05 & -0.91 & 2.78 \\
\hline Speak Hausa Language & 0.20 & 0.40 & 1.00 & 0.00 & $-0.80 * * *$ & 0.06 \\
\hline Speak Zarma Language & 0.70 & 0.48 & 0.00 & 0.00 & $0.70^{* * *}$ & 0.08 \\
\hline Gender & 0.29 & 0.46 & 0.05 & 0.23 & $0.24 * * *$ & 0.08 \\
\hline \multicolumn{7}{|l|}{ Firm Characteristics } \\
\hline Association Membership & 0.33 & 0.48 & 0.47 & 0.51 & -0.14 & 0.11 \\
\hline Years of Experience & 11.48 & 8.22 & 15.20 & 9.38 & $-3.78^{*}$ & 1.99 \\
\hline Number of employees & 3.44 & 5.10 & 4.00 & 3.11 & -0.56 & 0.94 \\
\hline Have partners & 0.29 & 0.46 & 0.24 & 0.49 & 0.06 & 0.11 \\
\hline Change original market & 0.08 & 0.27 & 0.11 & 0.31 & -0.03 & 0.07 \\
\hline Retailer & 0.59 & 0.50 & 0.55 & 0.50 & 0.03 & 0.11 \\
\hline Have financial account & 0.11 & 0.32 & 0.24 & 0.44 & -0.13 & 0.09 \\
\hline \multicolumn{7}{|l|}{ Trading Behavior } \\
\hline Number of markets followed & 2.82 & 1.92 & 3.50 & 3.96 & -0.68 & 0.71 \\
\hline Use mobile phone for trading & 0.44 & 0.50 & 0.38 & 0.49 & 0.06 & 0.08 \\
\hline Number of market contacts & 2.53 & 2.47 & 2.93 & 4.09 & -0.40 & 0.88 \\
\hline Number of purchase and sales markets & 3.51 & 1.96 & 4.53 & 2.88 & $-1.01 *$ & 0.56 \\
\hline Trade in markets within a $50-\mathrm{km}$ radius & 0.85 & 0.24 & 0.94 & 0.14 & $-0.09 *$ & 0.05 \\
\hline Take a loan & 0.36 & 0.48 & 0.38 & 0.49 & -0.02 & 0.10 \\
\hline Take a loan from a fellow trader & 0.21 & 0.42 & 0.23 & 0.42 & -0.01 & 0.09 \\
\hline Number of credit institutions & 0.50 & 0.70 & 0.67 & 0.67 & -0.02 & 0.10 \\
\hline Number of police controls & 1.00 & 1.38 & 1.83 & 1.20 & -0.83 & 1.35 \\
\hline Market tax (CFA/kg) & 0.75 & 0.25 & 0.92 & 0.14 & 0.17 & 0.17 \\
\hline Road quality ( $1=$ paved, $0=$ unpaved $)$ & 1.00 & 0.00 & 1.00 & 0.00 & 0.00 & 0.71 \\
\hline
\end{tabular}

Notes: Data from the Niger trader survey and secondary sources collected by Aker. N=415 traders, 35 markets. Huber-White robust standard errors are in parentheses. * is significant at the $10 \%$ level, ** significant at the $5 \%$ level, $* * *$ is significant at the $1 \%$ level. 